Manuscript BRFS-2019-0069.R1 accepted for publication in "Reviews in Fisheries Science \& Aquaculture"

Dear Professor Ringo:

Ref: Lactic Acid Bacteria in Shellfish: Possibilities and Challenges

Our referees have now considered your paper and have recommended publication in Reviews in Fisheries Science \& Aquaculture. We are pleased to accept your paper in its current form which will now be forwarded to the publisher for copy editing and typesetting.

\title{
Lactic Acid Bacteria in Shellfish: Possibilities and Challenges
}

\author{
Einar Ring $\emptyset^{1 *}$, Hien Van Doan ${ }^{2}$, Soonho Lee ${ }^{3}$ and Seong Kyu Song ${ }^{3}$
}

${ }^{1}$ Norwegian College of Fishery Science, Faculty of Bioscience, Fisheries and Economics, UiT The Arctic University of Norway, Troms $\varnothing$, Norway.

${ }^{2}$ Department of Animal and Aquatic Sciences, Faculty of Agriculture, Chiang Mai University, Chiang Mai 50200 Thailand.

${ }^{3}$ School of Life Science, Handong University, Pohang 37554, Republic of Korea.

* To whom correspondence should be addressed: Einar.Ringo@uit.no

\begin{abstract}
Several investigations have investigated the gut microbiota in shellfish species, but less information is available on the favourable gut bacteria colonising the GI tract, the lactic acid bacteria (LAB), and these studies have revealed the presence of Carnobacterium, Enterococcus, Lactobacillus, Lactococcus, Leuconostoc, Pediococcus, Streptococcus, Vagococcus and Weissella. Identification of LAB in shellfish digestive tract are equally distributed between culture methods and culture-independent techniques. In the majority of the studies, the LAB are identified from the whole intestine or intestinal contents, while less studies have evaluated the autochthonous LAB.

Some LAB isolated from shellfish are able to produce antibacterial substances towards different potential fish pathogenic bacteria. They also play an important role in improving the feed utilisation and act as effective growth promoters in shellfish, and increase diseases resistance of shellfish culture against infectious bacteria and virus. In addition, enhancement of rearing water quality and increase the resistance against stressful condition have been recorded in shellfish fed LAB diets.

LAB effects on the shellfish innate immune system are mostly studied in shrimp. In addition to LAB species studied in finfish or mammal systems, autochthonous strains of LAB are also used for studies. Generally, LAB-treated shellfish (crustaceans, mollusc, and Echinodermata)
\end{abstract}


significantly improve innate immune parameters and display an increased survival rate from pathogen infections. Some of the studies indicate that the treatment of LAB mixture shows better immunomodulatory effects than that of a single strain of LAB. Studies of the underlying mechanisms of shellfish innate immune regulation are required for the identification of speciesspecific probiotics and the correct assessment of immunological effects.

The present review paper focuses on recent findings in the field of isolation and detection of LAB in the GI tract of shellfish, some information on their presence in hepatopancreas and in muscle, their administration as probiotic, their mode of action, and their interaction with shellfish immune responses.

\section{INTRODUCTION}

Shellfish is important in aquaculture with high economic value on a global scale, and in recent years, the development of high-density zootechnology and recirculation shrimp farming systems have imposed enhanced stressors on shrimp. In this respect, evaluation of the gut microbiota is of importance, as the gut microbiota provide multitude biological functions including growth, metabolisms, development and immunity. Compared to endothermic animals, the gut microbiota of aquatic animals is less investigated, even though several comprehensive reviews and studies has been published during the last decade (e.g. Romero et al., 2014; Ring $\varnothing$ et al., 2016; Egerton et al., 2018). Even though several investigations have evaluated the microbial community in the gastrointestinal (GI) tract of shellfish (e.g. Zhang et al., 2014; Qiao et al., 2017; Sun et al. 2018; Li et al., 2018a), the topic is in early stages, and merits investigations, especially the beneficial gut bacteria; lactic acid bacteria (LAB). The favourable properties of $\mathrm{LAB}$, production of bacteriocins, hydrogen peroxide, short chain fatty acids (SCFAs), delivery system of nanobodies, and to prevent adherence and colonisation of pathogens in the GI tract have been discussed in several comprehensive reviews (e.g. De Vuyst and Leroy, 2007; Li et al., 2018b; Ring $\varnothing$ et al., 2018; del Rio et al., 2019).

The first study on shrimp microbiota was investigated by Tysset et al. (1961) using culturedependent agar plating techniques. Today it is generally accepted that one of the dominant phyla in the GI tract of shellfish is Firmicutes (e.g. Sha et al., 2016a; Lu et al., 2017; CornejoGranados et al., 2018; Li et al., 2018a; Gao et al., 2019a), but per se less investigations have accessed on LAB in the gut microbiota of shellfish. When discussing the importance of LAB in the GI tract of shellfish, it is important to evaluate the dietary effect, but few studies have investigated the dietary effect; for example the effect of dietary lipid and carbohydrate on the gut microbiota of shellfish (Wei et al., 2016; Zhang et al., 2014; Qiao et al., 2017; Sun et al., 2018, 2019; Panigrahi et al., 2019), but none of these studies revealed LAB in the GI tract.

Several reviews have reported that functional feed additives such as probiotics; derived from Greek and meaning for life, can improve growth performance, utilisation of dietary components, digestive functions, modulate the gut microbiota, enhance immunity and disease resistance of shellfish, and improve water quality (Farzanfar, 2006; Ninawe and Selvin, 2009; van Hai and Fotedar, 2010; Kumar et al., 2016; Hoseinifar et al., 2018, 2019; Li et al., 2018a). Among the probiotics used in shellfish aquaculture, LAB are one of the promising used, and the $2^{\text {nd }}$ aim of the present review is to present an update on LAB as probiotics in shellfish aquaculture, and on LAB data not mention in the aforementioned reviews.

Innate immunity is the first line defence system against pathogens in both vertebrates and invertebrates. Innate immune cells recognize microbes via pattern recognition receptors, which leads to the induction of immune responses, and eventually eliminates pathogens. Innate 
immune responses are directly dependant on the activated status of degradation enzymes, synthetic enzymes of reactive oxygen species, phagocytic cells, clotting proteins, and complement proteins (Tripp, 1974; Bayne, 1983; Gross et al., 1999; Sritunyalucksana et al., 2000; Kimbrell et al., 2001; Pasquier, 2001; Salzet, 2001; Tort et al., 2003; Beutler, 2004; Ausubel, 2005; Magnadottir et al., 2006; Vazquez et al., 2009; Harikrishnan et al., 2011; Ring $\varnothing$ et al., 2012, 2018; Chiaramonte et al., 2015; Romo et al., 2015; Song et al., 2015; SánchezSalgado et al., 2017; Smith et al., 2018). Generally, LAB affect various species including shellfish by improving their immune status, which leads to a more robust protection against various pathogens (Ige, 2013; Maeda et al., 2014; Merrifield et al., 2014; Vasama et al., 2014; Sha et al., 2016b; Ring $\varnothing$ et al., 2018). Additionally, LAB act as probiotics by demonstrating weight gain effects, modulating specific immune tone status, and inhibiting colonization of pathogens (Balcázar et al., 2006; Kim et al., 2013, 2016; Vasama et al., 2014; Yeh et al., 2014; Beck et al., 2015, 2016, 2017; Ring ø et al., 2018).

As the GI tract of aquatic organisms is one of the most important interfaces with the environment exposed to potential pathogens, and the fact that the GI tract is one of the major infection route (Birkbeck and Ring $\varnothing 2015$; Bøgwald and Dalmo 2014); the first aim of the present study address to evaluate the presence of LAB in the GI tract of shellfish. Furthermore, as LAB has the potential as probiotics and influence gut health, the current review aimed to present an updated overview of recently published data on health benefits of LAB as probiotics, their effect on the immune system.

As the present review do not discuss the pathogenicity of LAB, we recommend that readers with interest on this topic and disease control in shrimp aquaculture to have a closer look at the recent reviews of Xiong (2018) and Flegel (2019).

\section{LACTIC ACID BACTERIA (LAB) IN THE GASTROINTESTINAL (GI) TRACT OF SHELLFISH}

The GI tract microbiota in shellfish is divided into; the GI lumen microbiota (the allochthonous), and those that adhere to the mucosal surface (the autochthonous microbiota). In most shellfish studies, showed in Table 1, have characterized combination of allochthonous and autochthonous gut microbiota, isolated from the whole intestine with content, while few studies have focus on the autochthonous gut microbiota, which may be of importance in specialized physiological functions and by prevention adherence and colonisation of pathogens in the GI tract.

According to Merrifield et al. (2014) members belonging to Lactobacillus, Lactococcus, Leuconostoc, Enterococcus, Streptococcus, Carnobacterium, Pediococcus and Weissella genera are indigenous species in shellfish. In order to avoid duplication with that presented by Merrifield et al. (2014), lactic acid bacteria (LAB) isolated from the GI tract of Chinese shrimp (Fenneropenaeus chinensis), European lobster (Homarus gammarus), mud crab (Scylla paramamosain), swimming crab (Callinectes sp.), blue swimming crab (Portunus pelagicus), abalone (Haliotis asinina), oyster (Crassostrea corteziensis) and giant lion`s paw scallop (Nodipecten subnodosus) are not thoroughly discussed, only briefly presented. This subsection present investigations published post 2014 and papers not presented in the aforementioned review. Readers with special interest in studies only briefly presented in the text and in Table $\mathbf{1}$ are recommend to have a closer look at the review of Merrifield et al. (2014) or the original papers. 
Even though there is a paucity of studies which have investigated the indigenous gut bacteria in shellfish species compared to finfish, LAB have been reported in the GI tract of several shellfish species including shrimp, prawns, swimming crab (Callinectes and Portunus spp.) mud crab (Scylla paramamosain), scallop and abalone (Table 1).

The first study revealing LAB in the intestine of shellfish were displayed in giant freshwater shrimp (Macrobrachium rosenbergii) by Cai et al. (1999), where three isolates were identified to species level; Lactococcus garvieae, Pediococcus acidilactici and Enterococcus faecium by $16 \mathrm{~S}$ rRNA gene sequencing.

\section{Shrimp}

In a study focus on exopolysaccharides (EPSs), long-chain polysaccharides, secreted by marine bacteria, Hongpattarakere et al. (2012) reported that Lactobacillus plantarum isolated from shrimp gut microbiota revealed high production of EPSs. Recently, Zhou et al. (2019) reviewed exopolysaccharides of LAB, and revealed that EPSs are widely produced by LAB. The importance to isolate EPSs producing bacteria are; EPSs are suggested to play a protective role against, desiccation, toxic compounds, bacteriophages, osmotic stress, and to permit adhesion to solid surfaces and biofilm formation (De Vuyst and Degeest, 1999).

\section{Giant freshwater prawn (Macrobrachium rosenbergii)}

The first study reporting LAB in the GI tract of giant freshwater shrimp was carried out by Cai et al. (1999). Later, Lalitha and Surendran (2004) reported that Enterococcus spp. accounted for $8.3 \%$ of the identified gut bacteria in adult giant freshwater shrimp, while Kennedy et al. (2006) revealed a smaller proportion, $4.5 \%$ of the culturable microbiota belonged to genus Lactobacillus in larval gut. In a probiotic study of giant freshwater shrimp, Lb. plantarum obtained from the culture collection of Chandigarh, India was used as probiotics (Dash et al., $2014,2016)$, but in control fed prawn, only a small proportion (1.19 CFU g${ }^{-1}$ intestinal tissue) of Lactobacillus sp. was displayed, vs. total viable counts; $6.84 \mathrm{CFU} \mathrm{g}^{-1}$ intestinal tissue.

\section{Oriental river prawn (Macrobrachium nipponense)}

Tzeng et al. (2015) investigated the bacterial community in the gut of oriental river prawn, and revealed that sequences assigned to genus Lactobacillus were frequently (1.2-8.9\%) in all six libraries investigated, while sequences assigned to Streptococcus were low $(0.02-0.38 \%)$ in the libraries. In addition, Leuconostoc sp. was frequently revealed. Chen et al. (2017a) investigated the gut microbiomes using 16S rRNA amplicon sequencing on the Illumina MiSeq platform and revealed Latobacillales and Enterococcaceae. More recently, Zhao et al. (2018) explored the diversity and abundance of LAB in gut contents, allochthonous $\mathrm{LAB}$, in oriental river prawn, and displayed that LAB constituted up to approximately $56.5 \%$, and belonged to Streptococcaceae $(4.64 \pm 1.32 \%)$, Carnobacteriaceae $(3.62 \pm 0.98 \%)$, Aerococcaceae $(0.14 \pm$ $0.83 \%)$, Lactobacillaceae $(0.01 \pm 1.15 \%)$, Enterococaceae $(0.10 \pm 0.93 \%)$, and Leuconostocaceae $(0.01 \pm 0.13 \%)$. Among the genera, were Lactobacillus and Lactococcus reported as the major $\mathrm{LAB}$ in the shrimp intestine. When the authors compared the LAB community in the GI tract of different shrimp species, they suggested higher abundance of LAB in freshwater shrimp vs. seawater shrimp. This notification is of importance, and merits further investigations.

\section{Pacific white shrimp (Litopenaeus vannamei)}

Pacific white shrimp is an important aquaculture species with a high economic value on a global scale, and is the most investigated shellfish species with regard to LAB in the GI tract. In an 
early study, Vieira et al. (2007) isolated two LAB strains from the GI tract of juvenile Pacific white shrimp, and one of the strains later identified as Lb. plantarum, was used as probiotics (Vieira et al., 2008). In this study, total LAB counts in the intestine were low and not significantly different from control shrimps.

A previous study analyzing the bacterial community of Pacific white shrimp GI tract, revealed low population levels of Lactobacillus spp. and Streptococcus faecalis of both control and short-chain fructooligosaccharides (scFOS) fed shrimp (Zhou et al., 2007). Later. Vieira et al. (2010) identified LAB in the digestive tract of Pacific white shrimp, while Kosin and Rakshit (2010) identified Lb. plantarum and Leuconostoc mesenteroides subsp. mesenteroides/ dextranicum as autochthonous in the GI tract of Pacific white shrimp.

In the study of Kongnum and Hongpattarakere (2012), Lb. plantarum isolated from the intestinal tract of shrimp, species not specified, was used in a probiotic study, and cultivation analysis of the intestinal tract of Pacific white shrimp revealed LAB; coccoid shape and accounted for approximately $79 \%$ of total LAB isolated.

It is generally accepted that one of the most promising gut bacteria, is genus Bifidobacterium (Gibson et al., 2017). Boonanuntanasarn et al. (2016) investigated the gut microbiota of dietary supplementation of $\beta$-glucan and microencapsulated probiotics (Bacillus subtilis and Pediococcus acidilactici) in L. vannamei, and detected LAB and Bifidobacterium sp. by cultivation. Genus Bifidobacterium is seldom isolated from shellfish intestine, and the study of Boonanuntanasarn and co-authors was the first one isolating Bifidobacterium sp. in shellfish, and revealed approximately $\log 5.6 \mathrm{CFU} \mathrm{g}^{-1}$ intestine in the control fed group, but the population level did not varied by dietary treatment. Huang et al. (2016) analyzed the intestinal bacterial community at four stages, 14 days postlarvae and 1-, 2- and 3-months old Pacific white shrimp and reported Lactobacillaceae in 1 month old juvenile and Streptococcaceae in 3 month old juvenile by 454 pyrosequencing techniques. LAB was not detected in the other stages.

In a probiotic study with Pacific white shrimp, Lactobacillus and Enterococcus were not detected in the intestine, even though Lactobacillus pentosus and E. faecium were supplemented (Sha et al., 2016c). The authors suggested that this observation may be due to low abundance; too low to be detected or to low adhesion ability. The latter suggestion is possibly true, as the probiotic bacteria used were originally isolated from the gut of Hazekuchi (Acanthogobius hasta), and not from Pacific white shrimp. To confirm this suggestion further studies are needed. When discussing the adhesion ability, it is of importance to remember that the adhesion ability to mucin can greatly varied among $L b$. plantarum depending on their isolation habitats (Buntin et al., 2017).

In two studies, Adel et al. (2017a, 2017b) reported LAB in L. vannamei intestine. In a probiotic study using Pediococcus pentosaceus, previously isolated from healthy Pacific white shrimp intestine, Adel et al. (2017a) revealed $0.87 \pm 0.16 \times 10^{5} \mathrm{CFU} \mathrm{g}^{-1}$ intestine of Lactobacillus spp. in the control group, while $1.76 \pm 0.32 \times 10^{5} \mathrm{CFU} \mathrm{g}^{-1}$ intestine was detected in shrimp fed $10^{8}$ $P$. pentosaceus. These population levels are lower compared to the dominant one; Vibrio sp., $12.16 \pm 1.63 \times 10^{5} \mathrm{CFU} \mathrm{g}^{-1}$ intestine in the control group, and $11.58 \pm 1.4 \times 10^{5} \mathrm{CFU} \mathrm{g}^{-1}$ intestine of Micrococcus spp. by feeding L. vannamei $10^{6}$ P. pentosaceus. Adel et al. (2017b) identified a Lactococcus lactis subsp. lactis by biochemical analysis and 16S rRNA from intestine of $L$. vannamei, later used in a probiotic study. In the control group, not fed probiotics, the authors identified only a small proportion of Lactobacillus, $0.84 \pm 0.13 \mathrm{CFU} \mathrm{g}^{-1}$ intestine.

In a study evaluating the intestinal microbiome in a Pacific white shrimp grow-out pond with possible outbreak of acute hepatopancreatic necrosis disease, Chen et al. (2017b) revealed 11 order taxa of which one was Latobacillales (Weissella). 
The study of Cornejo-Granados et al. (2017) was the $2^{\text {nd }}$ study isolating Bifidobacterium from intestine of shellfish; healthy Pacific white shrimp, unique for cultured samples.

In a probiotic study, Duan et al. (2017) used Clostridium butyricum and revealed that probiotic supplementation enriched Lactobacillus sp. and Lactococcus sp. in the intestine of Pacific white shrimp. The authors put forward the controversial hypothesis that enrichment of Firmicutes, including LAB, might contribute to the expression of host digestive - and immune-related genes, but to fully conclude, further studies are needed. In an eight-week feeding trial, He et al. (2017) evaluated the gut bacterial community of Pacific white shrimp fed AviPlus ${ }^{\circledR}$ (AP), a blend of organic acids [citric acid, 25\%; sorbic acid, 16.7\%, and essential oils (thymol, 1.7\%; vanillin, 1.0\%)], and revealed that dietary inclusion of $1.2 \mathrm{~g} \mathrm{~kg}^{-1} \mathrm{AP}$ led to a significant increase in the abundance of Lactobacillus in shrimp gut $v$ s. control. In a study evaluating sulfide exposure on gut health and gut microbiota of Pacific white shrimp, Suo et al. (2017) reported genera belonging to Carnobacterium, Lactococcus, Lactobacillus, Leuconostoc, and Streptococcus in the GI tract. Generally, the relative abundance of the LAB strains were higher in the control group $v s$. group exposed to sulfide. It is also worth mention, that the relative abundance of Lactococcus was highest among the major bacteria in both treatment groups. Among the 26 families detected from the intestine of Pacific white shrimp, Lactobacillaceae was revealed (Xiong et al., 2017), but only a small indicator value (0.54) was noticed as Lactobacillaceae was only detected in the retarded and normal groups. Zeng et al. (2017) identified Lactobacillus sp. from the microbiota of the Pacific white shrimp intestine, but the abundance was low, $0.04 \%$, compared to the dominant taxa,Candidatus_Xiphinematobacter (3.4\%) and Propionigenium (3.4\%). Zheng and Wang (2017) isolated 18 presumptive LAB strains, via culture-dependent techniques on MRS agar medium from GI tract of Pacific white shrimp, and tested them for extracellular protease, cellulase and lipase activities. One of the most promising isolate, strain AS13 was further identified by $16 \mathrm{~S}$ rRNA gene sequence analysis and identified as $L b$. pentosus, and further used in a probiotic study.

Chomwong et al. (2018) identified Lb. plantarum and Lac. lactis from the intestinal microbiota of the Pacific white shrimp in a study evaluating the LAB activating effect on the proPO system, and revealed that $\mathrm{LAB}$ increase resistance of an acute hepatopancreatic necrosis disease of Vibrio parahaemolyticus. Scanning electron microscopy analysis revealed adherence of the shrimp gut, and antibacterial activity against the Gram-positive bacteria, Staphylococcus aureus, Aerococcus viridans, Bacillus megaterium and Bacillus subtilis, and the Gram-negative bacteria, V. parahaemolyticus, Vibrio harveyi and Escherichia coli. A general finding was; Lac. lactis revealed higher antibacterial activities than $L b$. plantarum.

Duan et al. (2018) explored the effect dietary poly- $\beta$-hydroxybutyrate (PHB) on the bacterial community of L. vannamei, and revealed that PHB increased the abundance of Lactobacillus sp. and Lactococcus sp., an effect that might improve shrimp intestinal health and disease resistance. In a comparative study analyzing the bacterial community in Pacific white shrimp intestine, rearing water and sediment, Lactobacillus sp. was one of the highly prevalent genus in the intestine (Hou et al., 2018). In addition, Streptococcus sp. was displayed. Synbiotic, combination of pro- and prebiotic, feeding using $L b$. plantarum and galactooligosaccharide (GOS), revealed modulation of the microbiota in L. vannamei intestine; improved colonization of Lb. plantarum and reduced abundance of Photobacterium damselae and $V$. harveyi (Huynh et al., 2018).

In a probiotic study, Pinoargote et al. (2018) displayed relative low abundance of Lactobacillaceae in the gut when Pacific white shrimp were fed the control diets; $0.009 \pm 0.003$ and $0.006 \pm 0.005$ in negative and positive control, respectively. The families, Rhodobacteraceae, Vibrionaceae and Lactobacillaceae in the Pacific white shrimp gut varied 
by supplementation of probiotics, but the relative abundance of Lactobacillaceae was significantly highest in shrimp fed $L b$. casei or the commercial product, $0.089 \pm 0.018$ and 0.148 \pm 0.027 , respectively.

Xue et al. (2018) investigated the gut bacterial community in Pacific white shrimp gut at four larval stages, and revealed Leuconostocaceae and Streptococcaceae at stage Z2 (zoea 2) and M1 (mysis 1), but only Leuconostocaceae at stage P1 (postlarvae 1). It is worth mention, that Streptococcaceae was one of the most abundant groups at stage Z2 and M1. Fan et al. (2019) evaluated the gut bacterial community of Pacific white shrimp, and revealed genus Lactobacillus in shrimp gut. Gao et al. (2019b) reported genera Lactobacillus and Streptococcus in L. vannamei intestine; the highest abundance was noticed in postlarvae fed Artemia nauplii enriched with Halomonas-PHB particles. In a study evaluating biological water purification grid (BWPG) on bacterial community of Pacific white shrimp intestine, Pei et al. (2019) revealed that Lactococcus was enriched in the water of the test pond treated with BWPG, but the genus was not detected in the intestine; dominated by unclassified bacteria, which may indicate that the environmental Lactococcus was not able to colonise the intestine.

\section{White shrimp (Penaeus vannamei)}

By culture-dependent techniques, Kongnum and Hongpattarakere (2012) isolated Lb. plantarum MRO3.12 from the GI tract of white shrimp, and the strain possessed high antibacterial activity towards $V$. harveyi. In addition, co-cultivation of $L b$. plantarum and $V$. harveyi, revealed complete reduction of the pathogen after $24 \mathrm{~h}$, under aerobic and anaerobic conditions, in contrast to an increase of strain MR03.12 from $\log 5.3$ to $9.5 \mathrm{CFU} \mathrm{mL} \mathrm{m}^{-1} . L b$. plantarum MRO3.12 was further used in a probiotic feeding trial with white shrimp. Sun et al. (2016) identified LAB from $P$. vannamei intestine, and these LAB were identified as Lactococcus sp. and Lactobacillus sp., but they accounted for a small proportion, 1.01 and 0.49 $\%$ of the intestinal bacterial community, respectively, compared to the dominant genus; Pseudomonas, $14.57 \%$. In a recent study, Gainza et al. (2018) explored the gut microbiota of $P$. vannamei in intensive ponds, harvest and nursery, and identified Lac. garvieae and Lactococcus sp. from harvest pond, while Lactobacillaceae was revealed in intestine of shrimp from the nursey pond.

\section{Brown shrimp (Farfantepenaeus californiensis)}

Only one study has revealed LAB in the intestine of brown shrimp (Leyva-Madrigal et al. 2011), and the authors addressed to isolate probiotic LAB to be used in Pacific white shrimp naturally infected with WSSV and IHHNV. Twenty presumptive LAB were isolated, and further analysis; haemolysis, growth, hydrophobicity, antibacterial activity against presumptive vibrios, and enzyme production revealed that the most promising isolates were identified as $P$. pentosaceus.

\section{Indian white shrimp (Penaeus indicus)}

Gopalakannan (2006) isolated $32 \mathrm{LAB}$, using culture-dependent methods, in the digestive tract of Indian white shrimp, and among them, LAB PI80 revealed high in vitro growth inhibition against Aeromonas hydrophila, and promising activity against Aeromonas salmonicida, Vibrio anguillarum, Vibrio fischeri, Vibrio vulnificus and V. parahaemolyticus. Kanmani et al. (2010) isolated Streptococcus phocae from the GI tract of Indian white shrimp, and tested the isolate for adherence, acid stability, antibiotic susceptibility, hemolytic properties and bacteriocins, 
and was further used in a challenge study with P. monodon (Pattukumar et al., 2014). In a later study, the strain was tested for exopolysaccharide production and antibiofilm activity (Kanmani et al., 2011).

\section{Kuruma shrimp (Marsupenaeus japonicus)}

Maeda et al. (2014) isolated 51 LAB strains from the digestive tract of kuruma shrimp and identified them as Enterococcus faecalis, Enterococcus, Enterococcus pseudovium, Enterococcus raffinosus, Lactobacillus sp. Lb. plantarum, Lactobacillus nagelii, Lac. garvieae, Lac. lactis, Pediococcus pentosaceus, Vagococcus campiphilus, Vagococcus sp. and Vc. fluvialis by $16 \mathrm{~S}$ ribosomal DNA sequencing. The 51 strains were tested for cellular immunomodulatory function by measuring the level of interferon (IFN)- $\gamma$ induction in mouse spleen cell culture, and the most promising strain Lac. lactis D1813 was selected as probiotic in a in vivo study of kuruma shrimp.

\section{Giant tiger prawn (Penaeus monodon)}

In a previous study, Gopalakannan (2006) isolated 18 LAB, using culture-dependent methods, in the digestive tract of giant tiger prawn, but none of them displayed promising in vitro growth inhibition against $A$. hydrophila. Nimrat et al. (2013) isolated an Enterococcus sp. S2 from the intestine of giant tiger prawn and tested its hemolytic activity, in vitro growth inhibition towards $V$. harveyi and extracellular enzyme activity. Based on its promising properties, the strain was used in a probiotic study with giant tiger prawn. Rungrassamee et al. (2014) revealed Lactobacillus sp. and Lactococcus sp. in the GI tract of wild caught giant tiger prawn.

\section{Yellow shrimp (Metapenaeus brevicornis)}

Only one study have isolated and identified presumptive LAB strains, via culture-dependent techniques, in the GI tract of yellow shrimp (Kongnum and Hongpattarakere 2012). The isolates were further tested for antibacterial effects against $V$. harveyi, and the general finding was that the lactobacilli possessed the highest antibacterial activity.

\section{Chinese shrimp (Fenneropenaeus chinensis)}

The first study revealing LAB, E. faecalis in the GI tract of the Chinese shrimp was carried out by DGGE (Liu et al. (2011). In a later study, Sha et al. (2016b) displayed that presumptive LAB from the intestine of Chinese shrimp revealed probiotic potential in a study using Pacific white shrimp

\section{Banana shrimp (Fenneropenaeus merguiensis)}

In a culture-dependent study, Kongnum and Hongpattarakere (2012) isolated presumptive LAB in the GI tract of banana shrimp, but the strains were not further identified, and further use was not given.

\section{European lobster (Homarus gammarus)}

Two studies by Daniels et al. (2010,2013) revealed Weissella confusa and Weissella cibaria in the GI tract of post-larval European lobster.

\section{Narrow clawed crayfish (Astacus leptodactylus)}

In a recent study, presumptive LAB was revealed in the intestine of narrow clawed crayfish fed diets supplemented 2 and $3 \%$ GOS by cultivation (Nedaei et al., 2019). The population level of LAB after 97 days of feeding was $\log$ CFU g ${ }^{-1}, 4.52 \pm 0.34$ and $4.23 \pm 0.26$ by feeding 2 and 
$3 \%$ GOS, respectively, but 14 days after switch to the basal diet, LAB counts was significantly reduced to approximately 2.6.

\section{Mud crab (Scylla paramamosain)}

A study assessing the GI tract of mud crabs identified Weissella fabaria, Streptococcus mutans and Latobacillales 1247 (Li et al., 2012).

\section{Swimming crab (Callinectes sp.)}

Uaboi-Egbenni et al. (2010) identified the well-known pathogen Streptococcus agalactiae in the GI tract of wild swimming crab.

\section{Blue swimming crab (Portunus pelagicus) and swimming crab (Portunus trituberculatus)} One previous study reported LAB in the GI tract of blue swimming carp (Talpur et al., 2012). More recently, Kim et al. (2017) evaluated the intestinal microbial community in wild caught swimming crab in spring and autumn, and revealed higher microbial diversity in autumn than in spring. The dominant genera in spring were, Psychrobacter, Vagococcus, Carnobacterium, Lactococcus and Streptococcus. In addition, detection of potential pathogens differed among sampling sites, site 2 and 6, in spring, especially the proportion of Lac. garvieae, $33.5 \%$ and $27.8 \%$, respectively.

\section{Chinese mitten crab (Eriocheir sinensis)}

Chinese mitten crab is an important species in South East Asia, and due to its high economic value it is widely farmed in China. Five studies assessing the GI tract of Chinese mitten crab identified the presence of LAB (Li et al., 2007; Chen et al., 2015; Zhang et al., 2016; Ding et al., 2017; Dong et al., 2018). Li et al. (2007) revealed uncultured Lactococcus sp. in the intestine of healthy and 1-year old wild Chinese mitten crab. Chen et al. (2015) explored the intestinal bacterial community of Chinese mitten crab farmed in Lake Tai, China, and displayed Latobacillales and Streptococcaceae by DGGE. Later, Zhang et al. (2016) evaluated the bacterial communities in water, gills and gut of wild caught E. sinensis, and showed that Tenericutes and Proteobacteria were the predominant gut phyla, but two OTUs showed high similarity to Lactococcus.

As white spot syndrome virus (WSSV) is an emerging problem in shellfish aquaculture industry, Ding et al. (2017) investigated the effect of WSSV infection on gut microbiota of Chinese mitten crab. Microbial DNA from 30 gut samples and revealed that the abundance of Latobacillales significantly decreased in WSSV infected Chinese mitten crab. In a study investigated the intestinal microbiota and expression of gut immunity genes, Dong et al. (2018) revealed that in fore-, mid- and hindgut, genus Lactococcus was one of the predominant genera, while the species was less abundant in mid- and hindgut, indicating that Lactococcus mostly colonize the foregut (FG). In addition to Lactococcus was Lactobacillus detected, the abundance was not specified.

\section{Abalone (Haliotis asinina)}

Sarkono et al. (2010) isolated four culturable presumptive LAB strains, identified as genus Lactobacillus, from the fluid of the digestive tract of abalone. 


\section{Giant lion`s paw scallop (Nodipecten subnodosus)}

Nava-Hernández (2008) identified LAB strain NS61 from the gut microbiota of the giant lion's paw scallop by using cultivation, but no further information was presented. Later, CampaCórdova et al. (2011), tested the strain as a probiotic for the oyster (Crassostrea corteziensis).

\section{LAB isolated from hepatopancreas}

In a study analyzing the effect of synbiotic (GOS and Ent. faecalis and P. acidilactici) feeding, Safari and Paolucci (2017) revealed low population levels of presumptive LAB in the hepatopancreas of control and GOS fed narrow-clawed crayfish.

\section{LAB isolated from shellfish muscle}

In their study evaluating six shellfish species, Japanese littleneck (Venerupis philippinarum), turbo (Batillus cornutus), Pacific oyster (Crassostrea gigas), Chinese venus (Cyclina sinensis), blue mussel (Mytilus edulis) and surf clam (Mactra veneriformis), Kang et al. (2016) revealed LAB from meat in all species, but no pathogens were detected. After testing for antibacterial activity towards several pathogens were four stains selected out of 65 presumptive Lactobacillus spp. isolated. $16 \mathrm{~S}$ rRNA analysis revealed high similarity to $\mathrm{Lb}$. plantarum. These LAB were further tested for bile salt- and acid tolerance and adhesion ability, and the authors suggested them as potential probiotics in shellfish aquaculture, but as no probiotic studies were carried out, further studies are needed.

In addition to the fact that several LAB strains have probiotic potential is has been revealed that certain species of LAB isolated from shellfish have the potential being causative agents of disease. In the early study of Cheng and Chen (1998), they isolated Enterococcus seriolicida from the muscle of diseased giant freshwater prawn, while Wang et al. (2008) isolated Lac. lactis subsp. lactis from diseased giant freshwater prawn muscle; a disease resulted in 100\% mortality in two days.

Braïek et al. (2018) isolated E. lactis from raw white shrimp, and tested the isolate for antibacterial activities against several Gram-positive strains including Enterococcus, Lactococcus, Micrococcus, Carnobacterium, Lactobacillus, Staphylococcus, Listeria and Bacillus, five Gram-negative species and 12 fungi species, and revealed production of enterocins A, B and or P, proteolytic activity, tolerance to bile and good autoaggregation and coaggregation capacities.

\section{PROBIOTIC LAB IN SHELLFISH}

\section{LAB as feed utilisation improvement}

Dietary inclusion of probiotics in aquatic animals is known to enhance feed digestion and absorption because of their abilities to release several digestive enzymes (etc. proteases, amylases, and lipases) and nutrients (etc. vitamins, amino acids, and fatty acids). These substances may take part in digestive process and feed utilization, as well as on the assimilation of diet elements resulted in improvement of host's health and growth (e.g. Irianto and Austin, 2002a; Bolasina et al., 2006; Ray et al., 2012; Hoseinifar et al., 2018, 2019; Ringø et al., 2018). Several studies have revealed altered enzyme patterns due to the intake of LAB in shellfish (Table 2).

Protease and amylase secretion have been elevated in Pacific white shrimp after feeding the shrimp Lactobacillus sp. at different dietary levels; $5 \%, 10 \%$, and $15 \%$ of basal diet (Wang et al., 2010). Dietary inclusion of Lac. lactis subsp. lactis isolated from shrimp's intestine significantly increased cellulose, lipase, amylase, and protease compared to the control (Adel 
et al., 2017). The significant increase in these enzyme activities may improve digestion and nutrient absorption, which in turn contributes to increase growth performance (Wang et al., 2012). It is well-established that the stimulation of digestive enzyme activities in fish and shellfish fed LAB may be attributable to the improvement of gut maturation (Tovar et al., 2002), prevention of intestinal disorders, and pre-digestion of antinutrient factors displayed in the feedstuffs (Verschuere et al., 2000). Similarly, significant improvement of protease and amylase activities were observed in L. vannamei fed P. pentosaceus at dose of $10^{7}$ and $10^{8}$ CFU/g. The authors also mentioned that the increase in shrimp's growth parameter and feed utilisation may be due to increase in digestive enzyme activity induced by the probiotics. When discusing the mode of action, probiotics might have the highest effects on the shrimp's digestive system in the ealy stage of life cycl, such the larval and early post-larval stages (Kamarudin et al., 1994; Lovett and Felder, 1990; Vine et al., 2006), and particularly LAB as they could release a broad range of exoenzymes (Moriarty, 1998). Furthermore, the presence of probiotics in shrimp's intestinal tract may induce the production of endogenous enzymes or contribute to the total enzyme activity of the gut (Saeed Ziaei-Nejad et al., 2006). The higher level of enzyme activities as a result of probiotics consumption could enhance the digestion and obsorption of protein, starch, fat, and cellulose, which might increase growth of shrimp fed the probiotic supplemented diets $v s$. the control. Dietary inclusion of commercial probiotic, Lb. plantarum at $10^{9} \mathrm{CFU} \mathrm{mL} \mathrm{m}^{-1}$ for 15 days significantly improved amylase, lipase, and pepsin activity of Pacific white shrimp. Recently, Du et al. (2019) revealed that dietary inclusion of Lb. pentosus significant increased trypsin, lipase, and $\alpha$-amylase in $L$. vannamei, while Zuo et al. (2019) indicated that administration of Lactobacillus significantly improved protease, lipase, and amylase of Pacific white shrimp. The enzymes mention above are important shrimp digestive enzymes which play an important role in the assimilation of nutrition in shrimp's intestine (Muhlia-Almazán et al., 2003). The concentrations of digestive enzymes were usually used as indicator for evaluating the shrimp's food conversion efficiency and growth performance, and many studies have demonstrated that dietary inclusion of probiotics could increased activity of trypsin, lipase, and $\alpha$-amylase enzymes (e.g. Ziaei-Nejad et al., 2006; Arena et al., 2007; Anand et al., 2014). Zuo et al. (2019) suggested enhanched enzyme actitities by supplementation of Lactobacillus might be due to enzyme secretions of Lactobacillus or by strengthened secretion from cells stimulated by the probiotic, or by the combinations of the two factors.

\section{LAB as effective growth promoters in shellfish}

The most importane goal of commercial aquaculture is to achieve fastest growth and low feeding input. To obtain the goal, the scientific community has developed different technologies that can boost growth performance of farmed animals by functional-additives and natural growth promoters (Katya et al., 2014; Hernández et al., 2016). In this respect, probiotics are of importance to obtain enhanched growth, improved health, and well-being aquatic animals, because they serve as nutrients source, vitamins and digestive enzymes, which in turn play an important role on feed utilization, nutrition absorption, and growth performance (Lauriano et al., 2016; Nath et al., 2018), and dietary inclusion of probiotic has been hypothesized to enhance the appetite or stimulate organisms' digestibility (Irianto and Austin, 2002b). Probiotics can enhance feed efficiency of fish and shellfish by stimulating the release of digestive enzymes and maintaining the balance or improving the intestinal bacterial commnity, which led to the improvement of nutrients absorption and utilization, as well as the survival and growth of the host (Irianto and Austin, 2002b; Ibrahem, 2015).

Several studies evaluating the effects of dietary inclusion of probiotics have revealed possible involvement of probiotics on the improvement of the intestinal microbiota balance as well as 
involved in the production of extracellular enzymes which by turns enahnce the feed utilization and growth of the cultured species as they act as growth promoters (Giri et al., 2013; Ring $\varnothing$ et al., 2018). Most studies using LAB in shellfish focus on growth performance and survival rate, for example; supplementation of E. faecium and Lac. garvieae at $10^{7} \mathrm{CFU} / \mathrm{mL}$ significantly enhance specific growth rate of $P$. monodon (Swain et al., 2009). Similar results were revealed by Vieira et al. (2010) in a study with $L$. vannamei administrated by Lb. plantarum isolated from Pacific white shrimp intestine. Kongnum and Hongpattarakere (2012) indicated significant higher relative growth rate and survival rate, and lower FCR in L. vannamei fed 2$4 \times 10^{8} \mathrm{CFU} \mathrm{g}^{-1}$ feed $\mathrm{Lb}$. plantarum for 6 weeks. Similarly, giant freshwater shrimp fed dietary inclusion of $L b$. plantarum showed significant increase in weight gain, specific growth rate, feed conversion efficiency, protein efficiency ratio, and carcass protein content; whereas feed conversion ratio (FCR) significant decreased (Dash et al., 2014, 2015, 2016). Significantly improved growth performance, total protein, total free amino acid, total carbohydrate, and total lipid content; as well as feeding rate, absorption rate, conversion rate, and excretory rate was observed in M. rosenbergii fed Lactobacillus sporogenes for 90 days (Seenivasan et al., 2014). Wang et al. (2010) revealed in a study using Lactobacillus sp. supplemented in L. vannamei diet; significant improved weight gain and specific growth rate, while FCR was reduced compared to the control treatment. Likely, significant increase larval survival rate was observed in Cortez oyster larvae (Crassostrea corteziensis) larvae fed dietary inclusion of LAB strain NS61 isolated from giant lion`s paw scallop at concentration of $10^{4}$ and $10^{5} \mathrm{CFU} / \mathrm{mL}$ (CampaCórdova et al., 2011), but no significant different in larval final size was revealed. Recently, dietary administration Lac. lactis subsp. lactis and P. pentosaceus significantly enhanced growth performance and FCR of L. vannamei (Adel et al., 2017a, 2017b). Similarly, Lb. pentosus and $L b$. plantarum inclusion in $L$. vannamei diets significantly improved growth performance and feed utilisation (Zheng and Wang, 2017; Zheng et al., 2017, 2018; Correa et al., 2018; Gao et al., 2018). It is known that LAB possesses high protein value, with a wide range of amino acids and trace elements. They are not only directly absorbed by the host as nutrients, but also secretes some SCFAs, vitamins, and other nutrients in order to maintain the host's gut ecological balance and enhance growth (e.g. Prieur et al., 1990; Verschuere et al., 2000; Irianto and Austin, 2002a). In addition, once the LAB adhere and colonized the intestine, they will release some digestive enzymes, such as cellulase, protease, and lipase into the host' intestinal tracts, and help the host digest residual food, which promotes the absorption of nutrients (Gallagher et al., 2001; Vine et al., 2006). Recently, Zuo et al. (2019) indicated that supplementation of Lactobacillus at $10^{7} \mathrm{CFU} \mathrm{g}^{-1}$ for 27 days significant increased the body weight of L. vannamei. Combination of several probiotics have shown to improve growth performance in shellfish; for example, Wang et al. (2019) revealed that combination of $L b$. pentosus, Laccoccus fermentum, B. subtilis, and Saccharomyces cerevisiae significantly improved growth performance and survival rate of L. vannamei, but no significant different in carcass composition was observed.

\section{LAB improve disease resistance in shellfish}

Probiotics have been proven as an effective tool for disease prevention in aquaculture (Hoseinifar et al., 2018; Ringø et al., 2018). Previously, antibiotics and chemotherapeutics were commonly applied for diseases prevention and treatment in aquaculture (Miranda et al., 2018), but the intensive applications of these substances have caused many adverse effects, such as the development of antibiotic-resistant bacteria, the residue of them in the aquaculture products, and the transferring of resistance genes from animals to human (Fair and Tor, 2014; Watts et al., 2017a; Santos and Ramos, 2018). As an alternative to antibiotics and chemotherapeutics, 
functional feed-additives, such as probiotics, prebiotics, and medicinal plants have gained attention in aquaculture (e.g. Akhter et al., 2015; Reverter et al., 2017). Probiotics can interact with or antagonize other enteric bacteria by resisting colonization or by directly inhibiting and reducing adherance and colonisation of opportunistic pathogens (Chiu et al., 2017). They can also improve host's health and well-being via physiological or immune modulation (Butt and Volkoff, 2019). In addition, they can produce a wide range of efficient molecules, which possess bactericidal activity. These molecules can inhibit pathogenic bacteria in the host's intestinal tract and provide a barrier against the proliferation of opportunistic pathogens (e.g. Martínez Cruz et al., 2012; Seghouani et al., 2017; Hoseinifar et al., 2018; Ring $\varnothing$ et al., 2018). The bioactive molecules produced during the bactericidal activity are antibiotics, bacteriocins, siderophores, enzymes (lysozymes, proteases), and/or hydrogen peroxide as well as organic acids (Verschuere et al., 2000; Hoseinifar et al., 2018; Ring $\varnothing$ et al., 2018). The inhibition of intestinal related diseases has been demonstrated in several aquaculure species via dietary inclusion of probiotics in aquafeeds (Ring ø et al., 2018; Wanka et al., 2018; Serra et al., 2019). Thus, it can be concluded that probiotics consumption can protect aquatic animals from infectious disease via the stimulation of immune systems. Dietary inclusion of $L b$. plantarum significantly increased disease resistance of Pacific white shrimp and giant freshwater shrimp against Vibrio alginolyticus, $V$. harveyi, and A. hydrophila, respectively (Chiu et al., 2007; Vieira et al., 2010; Kongnum and Hongpattarakere, 2012; Dash et al., 2015; Pacheco-Vega et al., 2018). In case of $L b$. pentosus, dietary inclusion significantly increased disease resistance of L. vannamei and Haliotis discus hannai against $V$. vulnificus, V. rotiferianus, V. campbellii, and V. parahaemolyticus, respectively (Zheng and Wang, 2017; Gao et al., 2018; Du et al., 2019). Similarly, administration of Lb. acidophilus and Lactobacillus significantly enhanced disease resistance of $L$. vannamei against $V$. alginolyticus and white spot syndrome virus, respectively (Sivakumar et al., 2012; Zuo et al., 2019). Resistance against Vibrio penaeicida and $V$. anguillarum was observed in Marsupenaeus japonicus and $L$. vannamei fed diet supplemented with Lac. lactis and Lac. lactis subsp. lactis, respectively (Maeda et al., 2014; Adel et al., 2017a). Supplementation of LAB strains from National Collection, Pune, India, was reported to improved disease resistance of $P$. indicus against $V$. parahaemolyticus; injected with $0.1 \mathrm{~mL}$ of $3 \times 10^{9}$ cells $\mathrm{mL}^{-1}$ (Ajitha et al., 2004). The probiotic bacterium, $P$. acidilactici supplemented in Litopenaeus stylirostris diets significantly enhanced disease resistance against V. nigripulchritudo (Castex et al., 2010). Combination of several probiotics in Pacific white shrimp diets, such as E. faecium, and Lb. pentosus or the combination of Lb. pentosus, Lac. fermentum, B. subtilis, and $S$. cerevisiae significantly improved disease resistance against $V$. parahaemolyticus (Sha et al., 2016; Wang et al., 2019), while the combination of E. faecalis and E. faecium showed significantly increased disease resistance of $L$. vannamei against $A$. hydrophila and V. vulnificus (Cui et al., 2017).

\section{LAB effects on rearing water quality}

The main obstacles in using antibiotics and chemotherapeutics to improve the rearing water quality in aquaculture is the emergence of antimicrobial-resistant bacteria (Akinbowale et al., 2006; Watts et al., 2017b), and as an alternative strategy; application of probiotics has been suggested. It has been reported that adding probiotics into water environment provided more favourable organisms than diet incorporation (Fuller, 1989). The interaction between water environment and aquacultured species have been considered as sustainable for aquaculture (e.g. Verschuere et al., 2000; Kesarcodi-Watson et al., 2008). The use of probiotics as a bioremediation tool to modulate the beneficial microorganism community and to inhibit pathogenic bacteria in the aquaculture environment led to the improvement aquatic animals' 
health status and performance (Rao, 2007; Martínez Cruz et al., 2012). For this purpose, probiotics have been produced commercially in several reasonable and specific preparations for fish, shrimp, and molluscs farming operations (Wang et al., 2005), but few studies have been conducted using LAB in shellfish aquaculture. Adding $L b$. plantarum directly into culture tank of $M$. rosenbergii revealed no effect on water quality (Dash et al., 2016). The synergistic elimilation of pathogens with simultaneous reduce ammonia, nitrite and nitrate concentration have been demonstrated in an in vitro assay using Lb. plantarum and Lb. hilgardii as potential probiotic (Ma et al., 2009). Nonetheless, water quality parameters were not improved compared to the control treatment. This finding may be due to that the experiment was conducted in small low density indoor system where the uneaten feed and faeces were removed and rearing water was exchanged frequently. Furthermore, the water quality was maintained in optimum range for $M$. rosenbergii culture. So, good management practice might masked the possible effect of Lb. plantarum on the water quality (Silva et al., 2012). Similarly, Correa et al. (2018) revealed that dietary inclusion of $L b$. plantarum had no effects on water qualtiy and pathogens removal in $L$. vannamei culutre under biofloc system. In contrast, dietary inclusion of Lb. plantarum significantly improved water quality and reduced shrimp diseases, as well as environmental impact (Pacheco-Vega et al., 2018).

\section{LAB against stressful conditions}

Intensification aquaculture with high density, normally caused stress for fish and shellfish (Guardiola et al., 2018), as stress will weaken the immune system of the host, and increase their susceptibility to infectious diseases (Kennedy et al., 2016). Stress is determined as 'physical or chemical factors that cause bodily reactions that may contribute to disease or death' (Rottmann et al., 1992). In addition to the physical and chemical stressors, the biological stress is defined as a 'nonspecific response of the body to any challenge' (Selye, 1982). According to the above definitions, there are many different stressors that aquatic animals faced during cultivation, such as transportation, malnutrition, stocking density, rearing temperature, anoxia, hypoxia, hyperoxia, chemicals, pesticides, and water salinity (e.g. Akhtar et al., 2011, 2013; Lushchak, 2011; Dawood et al., 2015a, 2015b).

Besides pathogen pressure, farmed finfish and shellfish are normally subjected to environmental disruption that can seriously affect their physiological condition and increase the oxidative stress (Lesser, 2006; Balasch and Tort, 2019). Therefore, probiotics are incorporated in aquafeed diets to ameliorate the effect of these oxidative stress factors. Supplementation of $P$. acidilactici at $10^{7} \mathrm{CFU} \mathrm{g}^{-1}$ feed for one month showed significantly improved antioxidant condition of Litopenaeus stylirostris (Castex et al., 2010). Hence, it is believed that probiotic consumption may promote the diet utilisation (Castex et al., 2008), and help to increase the absorption of dietary antioxidants from the feed. In addition, they play a vital role in antioxidant activity, as demonstrated for LAB (Kullisaar et al., 2002). Castex et al. (2010) assumed that anti-oxidative characteristics of a Lactobacillus fermentum strain may function as protective mechanisms in the intestinal microbial ecosystem and thus contribute to overcoming exo- and endogenous oxidative stressess. Recently, dietary inclusion of $L b$. plantarum significantly increased the resistance against stress, when shrimp were exposed to acute low salinity (Zheng et al., 2017). Probiotics have been used as effective tool to enhance shrimp's ability against environmental stress ( Yeh et al., 2010; Dong et al., 2013). It is known that there is a strickly order set of events occuring in order to help an organism response to the environemtal and physiological stressors. The most common mechanism is rapid changes in gene expression followed by the synthesis of proteins involved in adaptation (Zhou et al., 2010). Up-regulation of ProPO mRNA level was recorded in shrimp challenged by pathogens or environmental 
stress. It can be inferred that ProPO plays a critical role in shrimp immunity (Gao et al., 2009). Likely, dietary inclusion of $L b$. pentosus at different concentrations not only improves the antioxidant capacity of abalones, but also significantly decreases the MDA content. Furthermore, this inclusion can increase environmental adaptability, remain redox balance, and stimulate the immune function of abalone (Gao et al., 2018).

\section{SHELLFISH IMMUNE SYSTEM}

Various species of crustaceans, molluscs, and Echinodermata rely solely on innate immunity to fight against pathogens (Söderhäll et al., 1998; Zhang et al., 2004; McFall-Ngai et al., 2007; Loker et al., 2017). While further verification is required, some studies suggested that shellfish may also have an adaptive-like immune system (Arala-Chaves et al., 2000; Flajnik et al., 2004; Hibino et al., 2006; Kurtz et al., 2006; Vazquez et al., 2009; Chiaramonte et al., 2015; Song et al., 2015). Due to economic reasons, the immune systems of crustaceans, especially shrimp, are more heavily studied compared to molluscs or Echinodermata.

Shellfish contain phagocytic cells including dendritic cells, macrophages, and neutrophils. Dendritic cells and macrophages recognize microbe-derived molecules (microbe-associated molecular patterns, MAMPs) through pattern recognition receptors (PRRs) expressed on the cell surface or inside the cells. MAMPs include lipopolysaccharides, peptidoglycans, $\beta-1,3-$ glucans, lectins, and nucleic acids (Kaisho et al., 2004; Cerenius et al., 2010; Smith et al., 2010, 2018; Song et al., 2010; Sánchez-Salgado et al., 2017). Including Toll-like receptors (TRLs), 11 types of PRRs have been identified in shrimp (Wang et al., 2013). The presence of other types of PRRs, such as NOD-like receptors (NLRs) and RIG-like receptors (RLRs) need to be identified in shrimp and other shellfish species. The interaction between PRRs and MAMPs activates receptor-dependent signalling pathways, which results in innate immune responses: cytokine production and stimulation of phagocytosis, clotting proteins, apoptosis, antimicrobial proteins (AMPs), and the complement system (Kaisho et al., 2004; Cerenius et al., 2010; Smith et al., 2010, 2018; Song et al., 2010; Li et al., 2013; Sánchez-Salgado et al., 2017). C-type (Ca ${ }^{2+}$ dependent) lectins are most common in shellfish among the lectin groups. The carbohydrate recognition domain of lectins recognizes microbes determining the specificity (Rast et al., 2006; Vazquez et al., 2009; Sánchez-Salgado et al., 2017). Enzymatic defence systems, such as lysozymes, prophenoloxidase, and antioxidant enzymes are also crucial to combating numerous microbial infections. Activated defence enzymes cleave the peptidoglycan linkage between $\mathrm{N}$ acetylmuramic acid and $\mathrm{N}$-acetylglucosamine resulting in the elimination of microbes. Additionally, the enzymes inhibit melanin formation which is essential for microbe survival and reduce oxidative stress (Sritunyalucksana et al., 2000; Vazquez et al., 2009; Hauton, 2012; Chiaramonte et al., 2015). Phagocytic cells such as dendritic cells, monocytes, macrophages, and neutrophils engulf the microbes. Phagocytosis of microbes results in the direct killing inside phagocytes by lysosomal enzymes, reactive oxygen species, and nitric oxide (Battistella et al., 1996; Salzet et al., 2001; Cerenius et al., 2010; Hauton, 2012; Chiaramonte et al., 2015; Bouallegui, 2019). Clotting is a critical and rapid response required for sealing tissue injury, preventing pathogen infection via the damaged sites (Sritunyalucksana et al., 2000; Lee et al., 2002; Cerenius et al., 2011). Apoptosis is an essential cellular response to eliminate opportunistic harmful cells in shellfish, and apoptosis is highly regulated by numerous factors (Sokolova. 2009; Kiss, 2010; Menze et al., 2010). Antimicrobial peptides secreted from epithelial cells kill a broad range of Gram-positive and Gram-negative microbes (Vazquez et al., 2009; Hauton, 2012; Song et al., 2015; Smith et al., 2018). The complement system is also 
an essential innate defense component. Although the presence of the complement system in shellfish has been reported, further investigation is required (Gross et al., 1999; Nonaka and Yoshizaki, 2004; Song et al., 2015; Smith et al., 2018; Bouallegui, 2019).

\section{LAB EFFECTS ON CRUSTACEANS IMMUNE SYSTEM}

Most of the studies of LAB effects have mainly focused on shrimp. The effects of LAB administration on the innate immune systems of crab, shrimp, and crayfish are summarized in Table 3.

\section{Mud crab}

The LAB, $L b$. plantarum 7-40 originally isolated from fermented cabbage, kimchi, was fed to juvenile mud crab $(0.97 \mathrm{~g})$ as a powder-mixed diet $\left(10^{9} \mathrm{CFU} / \mathrm{kg}\right)$ for 28 days (Yeh et al., 2014), and the $L b$. plantarum-fed crabs showed higher growth performance than control fed crab. When challenged with $V$. parahaemolyticus $\left(10^{5} \mathrm{CFU} / \mathrm{crab}\right)$, the crabs treated with $L b$. plantarum revealed $17 \%$ increase in survival compared to the control group. In addition, the Lb. plantarum-treated group showed slightly elevated levels of total hemocyte count, phagocytic activity, and phenoloxidase activity. In contrast, the levels of respiratory burst, superoxide dismutase, and glutathione peroxidase were not significantly different between the experimental and control group.

\section{Blue swimming crab}

Talpur et al. (2013) treated swimming crab larvae for 14 days with indigenous $\mathrm{Lb}$. plantarum PPG-2-10-Talpur at three different concentrations: $1 \times 10^{6}, 5 \times 10^{6}$, and $1 \times 10^{7} \mathrm{CFU} / \mathrm{mL}$. The Lb. plantarum-treated group displayed increased survival, $9.5 \%, 10.8 \%$, and $8.3 \%$, respectively compared to the control group $(\sim 2.3 \%)$. Of note, there appears to be an ideal dose of $L b$. plantarum for beneficial survival effects, as feeding a high concentration $\left(1 \times 10^{7} \mathrm{CFU} / \mathrm{mL}\right)$ of Lb. plantarum PPG-2-10-Talpur caused a somewhat adverse effect on the larvae.

\section{Pacific white shrimp}

White shrimp were fed a diet containing $L b$. plantarum 7-40 at two different concentrations: $10^{7} \mathrm{CFU} / \mathrm{kg}$ and $10^{10} \mathrm{CFU} / \mathrm{kg}$ diet (Chiu et al., 2007). Immunological parameters were measured at different feeding periods: 24,48 , and 168 hours. After 24 hours of feeding, total hemocyte count, phenoloxidase activity, and respiratory burst were not significantly different between the $L b$. plantarum diet groups and the control group. After feeding for 48 hours and 168 hours, the shrimp were challenged with $V$. alginolyticus $\left(2 \sim 6 \times 10^{6} \mathrm{CFU} / \mathrm{shrimp}\right)$. The cumulative mortality of the shrimp was significantly reduced in the groups fed $L b$. plantarum $7-40$ (33.3\% and 23.3\%, respectively) compared to the control group (43.3\%). At 48 hours of feeding, the $L b$. plantarum-fed group showed significantly decreased total hemocyte count and phenoloxidase activity although these parameters enhanced after 168 hours of feeding. In contrast, the respiratory burst, clearance efficiency, and superoxide dismutase increased after 48 and 168 hours feeding. The gene expression levels of prophenoloxidase and peroxinectin were also significantly higher in the 168 hour-feeding groups. 
Sha et al. (2016b) fed white shrimp for 2 or 3 weeks on diets containing a mixture of $L b$. pentosus $\mathrm{HC}-2$ and E. faecium NRW-2 $\left(10^{7} \mathrm{CFU} / \mathrm{g}\right)$; originally isolated from the gut of Chinese

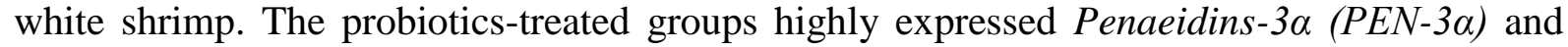
proPO genes in the midgut. When challenged with $V$. parahaemolyticus ATCC17802, the probiotics-fed shrimp significantly increased survival rates $(55.56 \%)$ compared to the control $(31.11 \%)$.

Wang et al. (2019) isolated $L b$. pentosus BD6 from pigeon faces, Lb. fermentum LW2 from Jingsi Lake water, and $S$. cerevisiae P13 from fermented peaches. The authors tested the immunological effects of these probiotics by feeding Pacific white shrimp with diets containing single or a mixture of the three bacteria in different concentrations $\left(10^{7}, 10^{8}\right.$ and $\left.10^{9} \mathrm{CFU} / \mathrm{kg}\right)$ for 56 days. All test groups showed no significant differences in total hemocyte numbers, but the $L b$. pentosus BD6 group and $S$. cerevisiae P13 group significantly increased phenoloxidase activity like the mixture-fed group. The respiratory burst activity was enhanced in all groups except the $L b$. fermentum LW2 and the $S$. cerevisiae group. All test groups increased lysozyme activity except the $S$. cerevisiae P13 group. Superoxide dismutase activity and phagocytic activity were slightly increased in all test groups compared to the control group. When challenged with $V$. alginolyticus infection, cumulative mortalities were significantly decreased in all the probiotic-treated groups ( $\mathrm{Lb}$. pentosus BD6: 40.7\%, Lb. fermentum LW2: 40\%, and S. cerevisiae P13: $53.3 \%$ ) in comparison to the control group (73.3\%). Strain mixture did not seem to have an effect on the mortality rates, as the shrimp fed with the mixture showed a similar mortality rate to those of the single strain-fed groups.

A commercially available product, PrimaLac ${ }^{\circledR}$ which included $L b$. acidophilus, Lb. casei, E. faecium, and B. bifidium was tested on white shrimp for 8 weeks at different doses: $0.25 \mathrm{~g}, 0.5$, and $1.0 \mathrm{~g} / \mathrm{kg}$ (Miandare et al., 2016). The genes of prophenoloxidase, lysozyme and antimicrobial peptides (penaidian and crustin) were expressed significantly higher in a dosedependent manner.

Vieira et al. (2010) tested innate immune activities of autochthonous Lb. plantarum by feeding the bacteria $\left(1.5 \times 10^{8} \mathrm{CFU} / \mathrm{g}\right)$ to Pacific white shrimp 4 times a day for 60 days. Although no difference was observed in the final body weight and natural death, total LAB numbers in the shrimp gut were highly increased after 20 days of feeding. When challenged with $V$. harveyi, the $L b$. plantarum-supplemented group showed a significantly higher survival rate $(65.7 \%)$ compared to that of the control group (39.9\%).

\section{Kuruma shrimp}

Immunomodulatory role of autochthonous $\mathrm{Lb}$. lactis D1813 was investigated by feeding Kuruma shrimp probiotic diets once a day for 14 days (Maeda et al., 2014). Both Lb. lactis D1813 groups $\left(10^{5}\right.$ and $\left.107 \mathrm{CFU} / \mathrm{g}\right)$ increased prophenoloxidase gene expression in the gut at 7 days of feeding. In contrast, the gene expressions of Anti-LPS factor, superoxide dismutase, and prophenoloxidase were marginally increased. When challenged by $\mathrm{V}$. penaeicida $\left(10^{8}\right.$ $\mathrm{CFU} / \mathrm{mL})$ at 14 days of feeding, the Lb. lactis D1813-fed group $\left(10^{5} \mathrm{CFU} / \mathrm{g}\right)$ exhibited an increased survival rate $(61.75 \%)$ compared to the control group (28.3\%). 


\section{Giant freshwater prawn}

Immune modulatory effects of $L b$. plantarum MTCC1407 were tested by feeding giant freshwater prawn at three different concentrations $\left(10^{7}, 10^{8}\right.$, and $10^{9} \mathrm{CFU} / \mathrm{g}$ ) (Dash et al., 2014). After 90 days of feeding, the shrimp significantly improved the innate immune parameters in a dose-dependent manner: total hemocytes, phenoloxidase activity, respiratory burst, and hemolymph clearance efficiency. The $L b$. plantarum-feeding groups showed significantly reduced cumulative mortalities $\left(10^{7} \mathrm{CFU} / \mathrm{g}: 60 \%, 10^{8} \mathrm{CFU} / \mathrm{g}: 40 \%\right.$, and $\left.10^{9} \mathrm{CFU} / \mathrm{g}: 31.11 \%\right)$ compared to the control group (82.23\%) when infected with A. hydrophila ATCC35654 (10 $\mathrm{CFU} /$ prawn). The same research group performed a similar study after heat-killing the same bacteria; at $60^{\circ} \mathrm{C}$ for $30 \mathrm{~min}$ (Dash et al., 2015). Giant freshwater prawns were fed heat-killed Lb. plantarum $\left(10^{7}, 10^{8}\right.$, and $\left.10^{9} \mathrm{CFU} / \mathrm{g}\right)$ for 90 days. LAB administration significantly increased the innate immune parameters in a dose-dependent manner, and mortality rates decreased significantly $\left(10^{7} \mathrm{CFU} / \mathrm{g}\right.$ group $\left.-71 \%, 10^{8} \mathrm{CFU} / \mathrm{g}-46 \%, 10^{9} \mathrm{CFU} / \mathrm{g}-38 \%\right)$ compared to the control group (84\%) when challenged with A. hydrophila ATCC35654 $\left(10^{6}\right.$ $\mathrm{CFU} /$ prawn). Furthermore, the same research group tested the water additive effect of $L b$. plantarum MTCC1407 by cultivating the shrimp in water supplemented the live bacteria for 90 days at three doses, $10^{7}, 10^{8}$, and $10^{9} \mathrm{CFU} / \mathrm{L}$ (Dash et al., 2016). When challenged with $A$. hydrophila ATCC35654 (106 $\mathrm{CFU} /$ prawn), the cumulative mortality rates of the LAB-treated group were reduced in a dose-dependent manner $\left(10^{7} \mathrm{CFU} / \mathrm{L}: 80 \%, 10^{8} \mathrm{CFU} / \mathrm{L}: 73.33 \%, 10^{9}\right.$ CFU/L: $62.23 \%$, and the control: $82.23 \%$ ). In addition the immune parameters were enhanced in a dose-dependent manner as well.

\section{Narrow-clawed crayfish}

Innate immune activities of $P$. acidilactici and E. faecalis were investigated on narrow-clawed crayfish (Safari et al., 2017). Juvenile crayfish were fed diets containing P. acidilactici (3.4 x $\left.10^{7} \mathrm{CFU} / \mathrm{g}\right)$, E. faecalis $(3.4 \times 107 \mathrm{CFU} / \mathrm{g})$, P. acidilactici $+\mathrm{GOS}(10 \mathrm{~g} / \mathrm{kg})$, or E. faecalis + GOS $(10 \mathrm{~g} / \mathrm{kg})$ for 126 days. Crayfish fed the E. faecalis + GOS diet revealed highest activities of phenoloxidase, superoxide dismutase, lysozyme, and nitric oxide synthase. When infected by $A$. hydrophila ATCC49040 $\left(1 \times 10^{8} \mathrm{CFU} / \mathrm{mL}\right)$, the mean survival rate of the crayfish fed with the E. faecalis + GOS diet was higher $(77.67 \%)$ than that of the control group $(8.33 \%)$ and the other groups $(58.33 \sim 72.33 \%)$.

\section{LAB EFFECTS ON MOLLUSCA IMMUNE SYSTEM}

The studies of LAB effects on mollusca are limited and are summarized in Table 3.

\section{Kumamoto oyster (Crassostrea sikamea)}

Abasolo-Pacheco et al. (2016) isolated $L b$. plantarum $\mathrm{C}$ from winged pearl oyster and $L$. graminis RL5 from lion's paw scallop. The probiotic effects of these two LAB strains were tested by cultivating juvenile oysters in water containing LAB $\left(1 \times 10^{6} \mathrm{CFU} / \mathrm{mL}\right)$ for 35 days. The oysters treated with the mixture of the isolates showed significantly higher growth rates compared to the control group, but it is hard to fully conclude as the growth rate was assessed with small size oysters (tens mg of body weights). 


\section{Catarina scallop (Argopecten ventricosus)}

The LAB strains isolated from oyster (Abasolo-Pacheco et al., 2016) were tested for their probiotics effects on catarina scallop (Abasolo-Pacheco et al., 2017). Larvae and juveniles were treated every 48 hours with a single or combined strain of probiotics $\left(1 \times 10^{6} \mathrm{CFU} / \mathrm{mL}\right)$ for nine days (larvae) and 21 days (juveniles). Early veliger larvae treated with $L b$. graminis RL5 and antibiotics or $L b$. plantarum $\mathrm{C} 3$ alone significantly improved survival and growth rates. The mixture of Bacillus (B. cereus PB1-1, B. flexus PB1-5, and B. firmus PB1-6 in 1:1:1 ratio) significantly enhanced survival of juveniles from $V$. alginolyticus CAIM57 challenge $\left(1 \times 10^{7}\right.$ $\mathrm{CFU} / \mathrm{mL})(60 \%)$ compared to the control $(0 \%)$, while juveniles treated with the LAB showed only $15 \%$ survival.

\section{New Zealand abalone (Haliotis iris)}

Autochthonous strains of probiotics (Exiguobacterium spp. JHEb1, Vibrio spp. JH1 and Enterococcus spp. JHLDc) were administered to farmed New Zealand abalone (Hadi et al., 2014). Juvenile abalones were fed for 60 days with diets containing the mix of two strains (2p: Exiguobacterium spp. JHEb1 and Vibrio spp. JH1, $2 \times 10^{8} \mathrm{CFU} / \mathrm{g}$ ) or the mixture of the three strains (3-P, $3 \times 10^{9} \mathrm{CFU} / \mathrm{g}$ ). The probiotics-fed abalones significantly increased maximum shell length (3-P: 20.9\%, 2-P: 15.4\%) and wet weight (3-P: 19.8\%, 2-P: 9.5\%). In addition, both the 2-P and 3-P group displayed significantly lower mortalities (3.33\%) than the control group (16.67\%). Theses autochthonous strains were further investigated over a four-month period by feeding juvenile abalones ( $1 \%$ body weight per day) with the mixture of the three strains $(2 \mathrm{x}$ $10^{9} \mathrm{CFU} / \mathrm{g}$ ) (Grandiosa et al., 2018). The probiotics-fed group significantly improved in growth compared to that of the control: length $(32.3 \%$ vs. $22.3 \%$, width $(31.9 \%$ vs. $20.9 \%)$ and wet weight (109.6\% vs. $72.8 \%$ ), respectively. Until 8 weeks of feeding, no significant differences in total hemocyte count and hemocyte viability were observed between the probiotics and the control group, but after 16 weeks of feeding, the probiotics-feeding group revealed significantly enhanced total hemocyte count and hemocyte viability. Furthermore, the probiotics group showed higher viability (90.8\% vs. $75.6 \%)$ and a higher percentage of ROS-positive cells (19.4\% vs. $0.5 \%$ ) compared to the control.

\section{LAB EFFECTS ON ECHINODERMATA IMMUNE SYSTEM}

Echinodermata has a sophisticated immune system including coelomocytes, clot formation factors, Toll-like receptors, NOD-like receptors, other lectins, complement factors, and antimicrobial peptides (Smith et al., 2018), but studies evaluating LAB effects on the Echinodermata immune system are limited.

\section{Sea cucumber (Actinopyga echinites)}

Juvenile sea cucumbers were fed diets including three probiotic strains of similar ratio (Lactobacillus, Sphingomonas, and Acetobacter) at two different concentrations $\left(6 \times 10^{7}\right.$ and 9 x $10^{7} \mathrm{CFU} / \mathrm{g}$ ) for 90 days (Bao et al., 2017). The probiotics-fed sea cucumbers significantly enhanced growth performance in a dose-dependent manner (control group: $10.6 \mathrm{~g}, 6 \times 10^{7}$ CFU/g group: $14.9 \mathrm{~g}, 9 \times 10^{7} \mathrm{CFU} / \mathrm{g}$ group: $15.4 \mathrm{~g}$ ). Immune parameters, such as superoxide dismutase, catalase, acid phosphatase, alkaline phosphatase, and lysozyme activity were also 
enhanced in a dose-dependent manner, but administration of $6 \times 10^{7} \mathrm{CFU} / \mathrm{g}$ did not significantly altered in lysozyme activity compared to the control.

\section{CONCLUSIONS}

When investigating the GI tract microbiota, one major concern occurs; most studies evaluating the shellfish gut microbiota have focus to characterize the communities in the GI lumen (the allochthonous microbiota), while those bacteria that adhere to the mucosal surface (the autochthonous microbiota); which may be important in specialized physiological functions, remain less investigated. We therefore recommend more focus on the autochthonous gut microbiota of shellfish in future studies.

Compared to finfish studies where the gut microbiota have been investigated in different (FG, MG and hindgut) segments (Ring $\varnothing$ et al., 2016; 2018), as differences may occur between the different segments. As limited numbers of studies have evaluated the bacterial community in the different intestinal segments of shellfish (Cheung et al., 2015; Ooi et al., 2017; Dong et al., 2018; Mongkol et al., 2018); scientists have to investigate the shellfish microbiota in different gut regions.

In shellfish GI tract the dominant LAB genera are Lactobacillus, Lactococcus and Enterococcus, while Leuconostoc, Pediococcus, Streptococcus, Vagococcus, Weissella, and Carnobacterium are generally seldom isolated.

In the comprehensive review of Ring $\varnothing$ et al. (2016) the dietary effect of finfish on gut microbiota was investigated, but less information is available on this topic in shellfish, as only few studies have investigated the dietary effect; lipid and carbohydrate on the gut microbiota of shellfish (Zhang et al., 2014; Qiao et al., 2017; Sun et al., 2018, 2019). In addition, insight into the function of the shellfish intestinal microbiota are needed as few studies have focus on this topic (Cornejo-Granados et al., 2018; Gao et al., 2019a).

This review reveal that Lactobacillus sp., Lactococcus sp., Pediococcus sp., Enterococcus faecalis, Bacillus subtilis, Saccharomyces cerevisiae, and other LAB strains have a potential in contributing to the successful and sustainable of shellfish farming by remaining the health and well-being of cultured animals ranging from improvement of growth, feed utilization, protection against infectious diseases, as well as decreasing stresses and the environmental impact induced by aquaculture industry. In conclusion, further investigations are needed to elucidate the effects of LAB on gut microbiota, nutrition utilization, and molecular responses to help in understanding the exact mode of action of LAB in mentioned parameters.

It is essential to understand the shellfish immune system and its regulatory mechanism in order to identify the proper probiotic candidates and accurate assessments of immunomodulatory effects in specific shellfish. While there is relatively active research being done involving the shrimp immune system, the current status of shrimp immunology is still far immature in comparison to those of mammals. Most of the studies focused on the identification of pattern recognition receptors and the downstream signaling pathways. Information about innate immune regulatory mechanisms, cytokine-producing cells, and target cells of cytokines, regulatory mechanisms of cytokines, and their effects on innate immunity needs to be further explored. Another critical aspect to consider is in regards to the changes in gut microbiomes of shellfish due to probiotic feedings and its effect on the health of the host shellfish. It is likely that microbe-associated molecular patterns of the altered gut microbiome affect the shellfish immune system, which may influence the status of the health status of the host. In addition, SCFAs released from the gut microbiome, such as butyric acids, may also contribute to the immune regulation of shellfish. 


\section{AUTHORS CONTRIBUTIONS}

ER: introduction, LAB in shellfish GI tract, editorial. HD: LAB as probiotics. SL and SS: immunology of LAB. All authors have approved the manuscript for publication.

\section{REFERENCES}

Abasolo-Pacheco, F., Campa-Córdova, A. I., Mazón-Suástegui, J. M., Tovar-Ramírez, D., Araya, R. and Saucedo, P. E. (2017). Enhancing growth and resistance to Vibrio alginolyticus disease in catarina scallop (Argopecten ventricosus) with Bacillus and Lactobacillus probiotic strains during early development. Aquaculture Research 48, 45974607. doi: 10.1111/are.13283

Abasolo-Pacheco, F., Saucedo, P. E., Mazón-Suástegui, J. M., Tovar-Ramírez, D., Araya, R., Ramírez-Orozco, J. M., et al. (2016). Isolation and use of beneficial microbiota from the digestive tract of lions-paw scallop Nodipecten subnodosus and winged pearl oyster Pteria sterna in oyster aquaculture. Aquaculture Research 47, 3042-3051. doi: 10.1111/are.12754

Adel, M., El-Sayed, A-F, M., Yeganeh, S., Dadar, M. and Giri, S.S. (2017a). Effect of probiotic Lactococcus lactis subsp. lactis on growth performance, intestinal microbiota, digestive enzyme activities, and disease resistance of Litopenaeus vannamei. Probiotics \& Antimicrobial Proteins 9, 150-156. doi: 10.1007/s12602-016-9235-9

Adel, M., Yeganeh, S., Dawood, M.A.O., Safari, R. and Radhakrishnan, S. (2017b). Effects of Pediococcus pentosaceus supplementation on growth performance, intestinal microflora and disease resistance of white shrimp, Litopenaeus vannamei. Aquaculture Nutrition 23, 1401-1409. doi: 10.1111/anu.12515

Ajitha, S., Sridhar, M., Sridhas, N., Singh, I.S.B. and Varghese, V. (2004). Probiotic effects of lactic acid bacteria against Vibrio alginolyticus in Penaeus (Fenneropenaeus) indicus (H. Milne Edwards). Asian Fisheries Science 17, 71-80.

Akhtar, M.S., Pal, A.K., Sahu, N.P., Alexander, C., and Meena, D.K. (2011). Dietary pyridoxine enhances thermal tolerance of Labeo rohita (Hamilton) fingerlings reared under endosulfan stress. Journal of Thermal Biology 36, 84-88. doi: 10.1016/j.jtherbio.2010.10.00

Akhtar, M.S., Pal, A.K., Sahu, N.P., Ciji, A., Meena, D.K., and Das, P. (2013). Physiological responses of dietary tryptophan fed Labeo rohita to temperature and salinity stress. Journal of Animal Physiology and Animal Nutrition 97, 1075-1083. doi: 10.1111/jpn.12017 10.1111/jpn.12017

Akhter, N., Wu, B., Memon, A.M., and Mohsin, M. (2015). Probiotics and prebiotics associated with aquaculture: A review. Fish \& Shellfish Immunology 45, 733-741. doi: 10.1016/j.fsi.2015.05.038

Akinbowale, O.L., Peng, H., and Barton, M.D. (2006). Antimicrobial resistance in bacteria isolated from aquaculture sources in Australia. Journal of Applied Microbiology 100, 1103-1113. doi: 10.1111/j.1365-2672.2006.02812.x

Anand, P.S.S., Kohli, M.P.S., Kumar, S., Sundaray, J.K., Roy, S.D., Venkateshwarlu, G., Sinha, A., and Pailan, G.H. (2014). Effect of dietary supplementation of biofloc on growth performance and digestive enzyme activities in Penaeus monodon. Aquaculture 418419, 108-115. doi: 10.1016/j.aquaculture.2013.09.051 
Arala-Chaves, M. and Sequeira, T. (2000). Is there any kind of adaptive immunity in invertebrates? Aquaculture 191, 247-258. doi: 10.1016/S0044-8486(00)00430-0

Arena, L., García, F., Regalado, I., Sosa, V., Cuzon, G., Gaxiola, G., and Rosas, C. (2007). Effect of diets with different carbohydrate concentrations in the growth, the phenotypic expression and specific activity of alpha-amylase in shrimp Penaeus (Litopenaeus) setiferus. Aquaculture 272, S241-S241. doi: 10.1016/j.aquaculture.2007.07.024

Ausubel, F. M. (2005). Are innate immune signalling pathways in plants and animals conserved? Nature Immunology 6, 937-979. doi: 10.1038/ni1253

Balcázar, J. L., Decamp, O., Vendrell, D., Blas, I. D. and Ruiz-Zarzuela, I. (2006). Health and nutritional properties of probiotics in fish and shellfish. Microbial Ecology in Health and Disease 18, 65-70. doi: 10.1080/08910600600799497

Balasch, J.C., and Tort, L. (2019). Netting the stress responses in fish. Frontiers in Endocrinology 10, 62. doi: 10.3389/fendo.2019.00062

Bao, N., Ren, T., Han, Y., Wang, F., Chen, F. and Jiang, Z. (2017). Alteration of growth, intestinal Lactobacillus, selected immune and digestive enzyme activities in juvenile sea cucumber Apostichopus japonicus, fed dietary multiple probiotics. Aquaculture International 25, 1721-1731. doi: 10.1007/s10499-017-0148-8

Battistella, S., Bonivento, P. and Amirante, G. A. (1996). Hemocytes and immunological reactions in crustaceans. Italian Journal of Zoology 63, 337-343. doi: $10.1080 / 11250009609356156$

Bayne, C. J. (1983). Molluscan immunobiology. Academic Press, 407-486. doi: 10.1016/B9780-12-751405-5.50016-6

Beck, B. R., Kim, D., Jeo,n J. S., Lee, S. M., Kim, H. K., Kim, O. J., et al. (2015). The effects of combined dietary probiotics Lactococcus lactis BFE920 and Lactobacillus plantarum FGL0001 on innate immunity and disease resistance in olive flounder (Paralichthys olivaceus). Fish \& Shellfish Immunology 42, 177-183. doi: 10.1016/j.fsi.2014.10.035

Beck, B. R., Lee, S. H., Kim, D., Park, J. H., Lee, H. K., Kwon, S. S., et al. (2017). A Lactococcus lactis BFE920 feed vaccine expressing a fusion protein composed of the OmpA and FlgD antigens from Edwardsiella tarda was significantly better at protecting olive flounder (Paralichthys olivaceus) from edwardsiellosis than single antigen vaccines. Fish \& Shellfish Immunology 68, 19-28. doi: 10.1016/j.fsi.2017.07.004

Beck, B. R., Song, J. H., Park, B. S., Kim, D., Kwak, J. H., Do, H. K., et al. (2016). Distinct immune tones are established by Lactococcus lactis BFE920 and Lactobacillus plantarum FGL0001 in the gut of olive flounder (Paralichthys olivaceus). Fish \& Shellfish Immunology 55, 434-443. doi: 10.1016/j.fsi.2016.06.022 
Beutler, B. (2004). Innate immunity: an overview. Molecular Immunology 40, 845-859. doi: 10.1016/j.molimm.2003.10.005

Birkbeck, T.H. and Ring $\varnothing$, E. (2005). "Pathogenesis and the gastrointestinal tract of growing fish" in Microbial Ecology in Growing Animals, eds W. Holzapfel and P. Naughton (Edinburgh, UK: Elsevier), 208-234.

Bolasina, S., Pérez, A., and Yamashita, Y. (2006). Digestive enzymes activity during ontogenetic development and effect of starvation in Japanese flounder, Paralichthys olivaceus. Aquaculture 252, 503-515. doi: 10.1016/j.aquaculture.2005.07.015

Boonanuntanasarn, S., Wongsasak, U., Pitaksong, T. and Chaijamrus, S. (2016). Effects of dietary supplementation with $\beta$-glucan and synbiotics on growth, haemolymph chemistry, and intestinal microbiota and morphology in the Pacific white shrimp. Aquaculture Nutrition 22, 837-845. doi: 10.1111/anu.12302

Bouallegui, Y. (2019). Immunity in mussels: an overview of molecular components and mechanisms with a focus on the functional defenses. Fish \& Shellfish Immunology 89, 158169. doi: 10.1016/j.fsi.2019.03.057

Braïek, O.B., Morandi, S., Cremonesi, P., Smaoui, S. and Hani, K. (2018). Safety, potential biotechnological and probiotic properties of bacteriocinogenic Enterococcus lactis strains isolated from raw shrimps. Microbial Pathogenesis 117, 109-117. doi: 10.1016/j.micpath.2018.02.021

Buntin, N., de Vos, W.M. and Hongpattarakere, T. (2017). Variation of mucin adhesion, cell surface characteristics, and molecular mechanisms among Lactobacillus plantarum isolated from different habitats. Applied Microbiology and Biotechnology 101, 7663-7674. doi: $10.1007 / \mathrm{s} 00253-017-8482-3$

Butt, R.L., and Volkoff, H. (2019). Gut microbiota and energy homeostasis in fish. Frontiers in Endocrinology 10. doi: 10.3389/fendo.2019.00009

Bøgwald, J. and Dalmo, R.A. (2014). "Gastrointestinal pathogenesis in aquatic animals" in Aquaculture Nutrition: Gut Health, Probiotics and Prebiotics, eds D. Merrifield and E. Ring $\varnothing$ (Oxford, UK: Wiley-Blackwell Publishing), 53-74. doi: 10.1002/9781118897263.ch3

Cai, Y., Suyanandana, P., Saman, P. and Benno, Y. (1999). Classification and characterization of lactic acid bacteria isolated from the intestines of common carp and freshwater prawns. Journal of General and Applied Microbiology 45, 177-184. doi: 10.2323/jgam.45.177

Campa-Córdova, A.I., Luna-González, A., Mazón-Suastegui, J.M., Aguirre-Guzmán, G., Ascencio, F. and González-Ocampo, H.A. (2011). Effect of probiotic bacteria on survival and growth of Cortez oyster larvae, Crassostrea corteziensis (Bivalvia: Ostreidae). Revista de Biologia Tropical 59, 183-191.

Castex, M., Chim, L., Pham, D., Lemaire, P., Wabete, N., Nicolas, J.-L., Schmidely, P., and Mariojouls, C. (2008). Probiotic P. acidilactici application in shrimp Litopenaeus stylirostris culture subject to vibriosis in New Caledonia. Aquaculture 275, 182-193. doi: 10.1016/j.aquaculture.2008.01.011

Castex, M., Lemaire, P., Wabete, N., and Chim, L. (2010). Effect of probiotic Pediococcus acidilactici on antioxidant defences and oxidative stress of Litopenaeus stylirostris under Vibrio nigripulchritudo challenge. Fish \& Shellfish Immunology 28, 622-631. doi: 10.1016/j.fsi.2009.12.024 
Cerenius, L. and Söderhäll, K. (2011). Coagulation in invertebrates. Journal of Innate Immunity 3, 3-8. doi: 10.1159/000322066

Cerenius, L., Jiravanichpaisal, P., Liu, H. P. and Söderhäll, I. (2010). Crustacean immunity. Advances in Experimental Medicine and Biology, 708. 239-259. doi: 10.1007/978-1-44198059-5_13

Chen, X., Di, P., Wang, H., Li, B., Pan, Y., Yan, S., et al. (2015). Bacterial community associated with the intestinal tract of Chinese mitten crab (Eriocheir sinensis) farmed in lake Tai, China. PLoS ONE 10, e0123990. doi: 10.1371/journal.pone.0123990

Chen, C-Y., Chen, P-C., Cheng-Hsuan Weng, F., Shaw, G.T-W. and Wang, D. (2017a). Habitat and indigenous gut microbes contribute to the plasticity of gut microbiome in oriental river prawn during rapid environmental change. PLoS ONE 12, e0181427. doi: 10.1371/journal.pone.0181427

Chen, W-Y., Ng, T.H., Wu, J-H., Chen, J-W. and Wang, H-C. (2017b). Microbiome dynamics in a shrimp grow-out pond with possible outbreak of acute hepatopancreatic necrosis disease. Scientific Reports 7, 9395. doi: 10.1038/s41598-017-09923-6

Cheng, W.T. and Chen, J.C. (1998). Isolation and characterization of an Enterococcus-like bacterium causing muscle necrosis and mortality in Macrobrachium rosenbergii in Taiwan. Diseases of Aquatic Organisms 34, 93-101. doi: 10.3354/dao34093

Cheung, M.K., Yip, H.Y., Nong, W., Wan Law, P.T., Chu, K.H., Kwan, H.S., et al. (2015). Rapid change of microbiota diversity in the gut but not in hepatopancreas during gonadal development of the new shrimp model Neocaridina denticulata. Marine Biotechnology 17, 811-819- doi: 10.1007/s10126-015-9662-8

Chiaramonte, M. and Russo, R. (2015). The echinoderm innate humoral immune response. Italian Journal of Zoology 82, 300-308. doi: 10.1080/11250003.2015.1061615

Chiu, C. H., Guu, Y. K., Liu, C. H., Pan, T. M. and Cheng, W. (2007). Immune responses and gene expression in white shrimp, Litopenaeus vannamei, induced by Lactobacillus plantarum. Fish \& Shellfish Immunology 23, 364-377. doi: 10.1016/j.fsi.2006.11.010

Chiu, L., Bazin, T., Truchetet, M.-E., Schaeverbeke, T., Delhaes, L., and Pradeu, T. (2017). Protective microbiota: From localized to long-reaching co-immunity. Frontiers in Immunology 8, 1678. doi: 10.3389/fimmu.2017.01678

Chomwong, S., Charoensapsi, W., Amparyup, P. and Tassanakajon, A. (2018). Two host gutderived lactic acid bacteria activate the proPO system and increase resistance to an AHPND-causing strain of Vibrio parahaemolyticus in the shrimp Litopenaeus vannamei. Developmental and Comparative Immunology 89, 54-66. doi: 10.1016/j.dci.2018.08.002

Correa, N.M., Bolivar Ramirez, N.C., Legarda, E.C., Rocha, J.S., Seiffert, W.Q., and Vieira, F.D.N. (2018). Dietary supplementation with probiotic and butyrate in the shrimp nursery in Biofloc. Boletim Do Instituto De Pesca 44, e348. doi: 10.20950/16782305.2018.348

Cornejo-Granados, F., Lopez-Zavala, A.A., Gallardo-Becerra, L., Mendoza-Vargas, A., Sánchez, F., Vichido, R., et al. (2017). Microbiome of Pacific whiteleg shrimp reveals differential bacterial community composition between wild, aquacultured and 
AHPND/EMS outbreak conditions. Scientific Reports 7, 11783. doi: 10.1038/s41598-01711805-w

Cornejo-Granados, F., Gallardo-Becerra, L., Leonardo-Reza, M., Ochoa-Romo, J.P. and Ochoa-Leyva, A. (2018). A meta-analysis reveals the environmental and host factors shaping the structure and function of shrimp microbiota. PeerJ 6, e5382. doi: 10.7717/peerj.5382

Corrêa, N.M., Ramírez, N.C.B., Legarda, E.C., Rocha, J.S., Seiffert, W.Q. and Vieira, F. doN. (2018) Dietary supplementation with probiotic and butyrate in the shrimp nursery in biofloc. Boletim do Instituto de Pesca 44, e348. doi: 10.20950/1678-2305.348.

Cui, J., Xiao, M., Liu, M., Wang, Z., Liu, F., Guo, L., et al. (2017). Coupling metagenomics with cultivation to select host-specific probiotic micro-organisms for subtropical aquaculture. Journal of Applied Microbiology 123, 1274-1285. doi: 10.1111/jam. 13555 Daniels, C.L., Merrifield, D.L., Boothroyd, D.P., Davies, S.J., Factor, J.R. and Arnold, K.E. (2010). Effect of dietary Bacillus spp. and mannan oligosaccharides (MOS) on European lobster (Homarus gammarus L.) larvae growth performance, gut morphology and gut microbiota. Aquaculture 304, 49-57. doi: 10.1016/j.aquaculture.2010.03.018

Daniels, C.L., Merrifield, D.L., Ring ø, E. and Davies, S.J. (2013). Bacterial manipulation in the gastrointestinal tract of larval stage, European lobster, Homarus gammarus: using biotic dietary supplements to improve culture success. Aquaculture 416-417, 396-406. doi: 10.1016/j.aquaculture.2013.08.001

Dash, G., Raman, R.P., Prasad, K.P., Makesh, M., Pradeep, M.A. and Sen, S. (2014). Evaluation of Lactobacillus plantarum as feed supplement on host associated microflora, growth, feed efficiency, carcass biochemical composition and immune response of giant freshwater prawn, Macrobrachium rosenbergii (de Man, 1879). Aquaculture 432, 225-236. doi: 10.1016/j.aquaculture.2014.05.011

Dash, G., Raman, R.P., Prasad, K.P., Makesh, M., Pradeep, M.A. and Sen, S. (2015). Evaluation of paraprobiotic applicability of Lactobacillus plantarum in improving the immune response and disease protection in giant freshwater prawn, Macrobrachium rosenbergii (de Man, 1879). Fish \& Shellfish Immunology 43, 167-174. doi: 10.1016/j-fsi.2014.12.007

Dash, G., Raman, R.P., Prasad, K.P., Makesh, M., Pradeep, M.A. and Sen, S. (2016). Evaluation of Lactobacillus plantarum as a water additive on host associated microflora, growth, feed efficiency and immune response of giant freshwater prawn, Macrobrachium rosenbergii (de Man, 1879). Aquaculture Research 47, 804-818. doi: 10.11111/are.12539

Dawood, M.A.O., Koshio, S., Ishikawa, M., and Yokoyama, S. (2015a). Effects of heat killed Lactobacillus plantarum (LP20) supplemental diets on growth performance, stress resistance and immune response of red sea bream, Pagrus major. Aquaculture 442, 29-36. doi: 10.1016/j.aquaculture.2015.02.005

Dawood, M.A.O., Koshio, S., Ishikawa, M., and Yokoyama, S. (2015b). Effects of partial substitution of fish meal by soybean meal with or without heat-killed Lactobacillus plantarum (LP20) on growth performance, digestibility, and immune response of amberjack, Seriola dumerili Juveniles. BioMed Research International 514196. doi: $10.1155 / 2015 / 514196$

del Rio, B., Redruello, B., Fernandez, M., Cruz, M.M., Ladero, V., et al. (2019) Lactic acid bacteria as a live delivery system for the in situ production of nanobodies in the human gastrointestinal tract. Frontiers in Microbiology 9, 3179. doi: 10.3389/fmicb.2018.03179

De Vuyst, L. and Degeest, B. (1999). Heteropolysaccharides from lactic acid bacteria. FEMS Microbiology Reviews 23, 153-177. doi: 10.1016/S0168-6445(98)00042-4 
De Vuyst, L. and Leroy, F. (2007). Bacteriocins from lactic acid bacteria: Production, purification and food applications. Journal of Molecular Microbiology and Biotechnology 13, 194-199. doi: 10.1159/000104752

Ding, Z.F., Cao, M.J., Zhu, X.S., Xu, G.H. and Wang, R.L. (2017). Changes in the gut microbiome of the Chinese mitten crab (Eriocheir sinensis) in response to white spot syndrome virus (WSSV) infection. Journal of Fish Diseases 40, 1561-1571. doi: $10.1111 /$ jdf.12624

Dong, Y., Wang, C., and Pan, Q. (2013). "Dynamic evaluation of wind turbine health condition based on multi-source information fusion", in: Advanced Materials Research, eds Y. Li, Y. Li and W. P, 607-610. doi: 10.4028/www.scientific.net/AMR.608-609.607

Dong, J., Li, X., Zhang, R., Zhao, Y., Wu, G., Liu, J., et al. (2018). Comparative analysis of the intestinal bacterial community and expression of gut immunity genes in the Chinese mitten crab (Eriocheir sinensis). AMB Express 8, 192. doi: 10.1186/s13568-018-0722-0

Du, Y., Wang, B., Jiang, K., Wang, M., Zhou, S., Liu, M., and Wang, L. (2019). Exploring the influence of the surface proteins on probiotic effects performed by Lactobacillus pentosus HC-2 using transcriptome analysis in Litopenaeus vannamei midgut. Fish \& Shellfish Immunology 87, 853-870. doi: 10.1016/j.fsi.2019.02.027

Duan, Y., Zhang, Y., Dong, H., Wang, Y. and Zhang, J. (2017). Effects of poly- $\beta$ hydroxybutyrate (PHB) on microbiota composition and the mTOR signaling pathway in the intestine of Litopenaeus vannamei. Journal of Microbiology 55, 946-954. doi: 10.1007/12275-017-7273 y

Duan, Y., Wang, Y., Dong, H., Liu, Q., Li, H., Zhang, J., et al. (2018). Changes in the intestine microbial, digestive, and immune-related genes of Litopenaeus vannamei in response to dietary probiotic Clostridium butyricum supplementation. Frontiers in Microbiology 9, 2191. doi: $10.3389 /$ fmicb.2018.02191

Egerton, S., Culloty, S., Whooley, J., Stanton, C. and Ross, R.P. (2018). The gut microbiota of marine fish. Frontiers in Microbiology 9, 873. doi: 10.3389/fmicb.2018.00873

Fair, R.J. and Tor, Y. (2014). Antibiotics and bacterial resistance in the 21st century. Perspectives in Medicinal Chemistry 6, 25-64. doi:10.4137/PMC.S14459

Fan, J., Chen, L.M., Mai, G.Q., Zhang, H.R., Yang, J., Deng, D., et al. (2019). Dynamics of the gut microbiota in developmental stages of Litopenaeus vannamei reveal its association with body weight. Scientific Reports 9, 734- doi: 10.1038/s41598-018-37042-3

Farzanfar, A. (2006) The use of probiotics in shrimp aquaculture. FEMS Immunology and Medical Microbiology 48, 149-158- doi: 10.1111/j.1574-695X.2006.00116.x

Flajnik, M. F. and Pasquier, L. D. (2004). Evolution of innate and adaptive immunity: can we draw a line? Trends in Immunology 25, 640-644. doi: 10.1016/j.it.2004.10.001

Flegel, T.W. (2019). A future vision for disease control in shrimp aquaculture. Journal of the World Aquaculture Society, doi: 10.1111/jwas.12589

Fuller, R. (1989). Probiotics in man and animals. Journal of Applied Bacteriology 66, 365-378. doi: 10.1111/j.1365-2672.1989.tb05105.x

Gainza, O., Ramírez, C., Ramos, A.S. and Romero, J. (2018). Intestinal microbiota of white shrimp Penaeus vannamei under intensive cultivation conditions in Ecuador. Microbial Ecology 75, 562-568. doi: 10.1007/s00248-017-1066-Z 
Gallagher, M.L., Luczkovich, J.J., and Stellwag, E.J. (2001). Characterization of the ultrastructure of the gastrointestinal tract mucosa, stomach contents and liver enzyme activity of the pinfish during development. Journal of Fish Biology 58, 1704-1713. doi: 10.1006/jfbi.2001.1581

Gao, H., Li, F., Dong, B., Zhang, Q., and Xiang, J. (2009). Molecular cloning and characterisation of prophenoloxidase (ProPO) cDNA from Fenneropenaeus chinensis and its transcription injected by Vibrio anguillarum. Molecular Biology Reports 36, 1159-1166. doi: 10.1007/s11033-008-9292-6

Gao, X., Zhang, M., Li, X., Han, Y., Wu, F., and Liu, Y. (2018). The effects of feeding Lactobacillus pentosus on growth, immunity, and disease resistance in Haliotis discus hannai Ino. Fish \& Shellfish Immunology 78, 42-51. doi: 10.1016/j.fsi.2018.04.010

Gao, S., Pan, L., Huang, F., Song, M., Tian, C. and Zhang, M. (2019a). Metagenomic insight into the structure and function of intestinal microbiota of the farmed Pacific white shrimp (Litopenaeus vannamei). Aquaculture 499, 109-118. doi: 10.1016/j.aquaculture.2018.09.026

Gao, M., Du, D., Bo, Z. and Sui, L. (2019b) Poly- $\beta$-hydroxybutyrate (PHB)-accumulating Halomonas improves the survival, growth and modifies the gut microbial composition of Litopenaeus vannamei postlarvae. Aquaculture 500, 607-612. doi: 10.1016/j.aquaculture.2018.032

Gibson, R., Hutkins, R., Sanders, M.E., Prescott, S., Reimer, R.A., Salminen, S., et al. (2017). The international scientific association for probiotics and prebiotics (ISAAPP) consensus statement on the definition and scope of prebiotics. Nature Reviews Gastroenterology \& Hepatology 14, 491-502. doi: 10.1038/nrgastro.2017.75

Giri, S.S., Sukumaran, V., and Oviya, M. (2013). Potential probiotic Lactobacillus plantarum VSG3 improves the growth, immunity, and disease resistance of tropical freshwater fish, Labeo rohita. Fish \& Shellfish Immunology 34, 660-666. doi: 10.1016/j.fsi.2012.12.008

Grandiosa, R., Mérien, F., Young, T., Nguyen, T. V., Gutierre, N., Kitundu, E., et al. (2018). Multi-strain probiotics enhance immune responsiveness and alters metabolic profiles in the New Zealand black-footed abalone (Haliotis iris). Fish \& Shellfish Immunology 82, 330338. doi: 10.1016/j.fsi.2018.08.034

Gopalakannan, A. (2006). Studies on the control of Aeromonas hydrophila infection in Cyprinus carpio and tilapia Mossambicus by immunostimulants and probiotics. Ph.D. thesis, Department of Biotechnology, School of Life Sciences, Pondicherry University, India.

Gross, P. S., Al-Sharif, W. Z., Clow, L. A. and Smith, L. C. (1999). Echinoderm immunity and the evolution of the complement system. Developmental and Comparative Immunology 23, 429-442. doi: 10.1016/S0145-305X(99)00022-1

Guardiola, F. A., Saraiva-Fraga, M., Cuesta, A. and Esteban, M. A. (2018). Changes in natural haemolytic complement activity induced by stress in gilthead seabream (Sparus aurata L.). Fish \& Shellfish Immunology 78, 317-321. doi:_10.1016/j.fsi.2018.04.056

Hadi, J. A., Gutierrez, N., Alfaro, A. C. and Roberts, R. D. (2014). Use of probiotic bacteria to improve growth and survivability of farmed New Zealand abalone (Haliotis iris). New 

10.1080/00288330.2014.909857

Harikrishnan, R., Balasundaram, C. and Heo, M. S. (2011). Impact of plant products on innate and adaptive immune system of cultured finfish and shellfish. Aquaculture 317, 1-15. doi: 10.1016/j.aquaculture.2011.03.039

Hauton, C. (2012). The scope of the crustacean immune system for disease control. Journal of Invertebrate Pathology 110, 251-260. doi: 10.1016/j.jip.2012.03.005

He, W., Rahimnejad, S., Wang, L., Song, K., Lu, K. and Zhang, C. (2017). Effects of organic acids and essential oils blend on growth, gut microbiota, immune response and disease resistance of Pacific white shrimp (Litopenaeus vannamei) against Vibrio parahaemolyticus. Fish \& Shellfish Immunology 70, 164-173. doi: 10.1016/j.fsi.2017.09.007

Hernández, A.J., Romero, A., Gonzalez-Stegmaier, R., and Dantagnan, P. (2016). The effects of supplemented diets with a phytopharmaceutical preparation from herbal and macroalgal origin on disease resistance in rainbow trout against Piscirickettsia salmonis. Aquaculture 454, 109-117. doi: 10.1016/j.aquaculture.2015.12.016

Hibino, T., Loza-Coll, M., Messier, C., Majeske, A. J., Cohen, A. H., Terwilliger, D. P., et al. (2006). The immune gene repertoire encoded in the purple sea urchin genome. Developmental Biology 300, 349-365. doi: 10.1016/j.ydbio.2006.08.065

Hongpattarakere, T., Cherntong, N., Wichienchot, S., Kolida, S. and Rastall, R.A. (2012). In vitro prebiotic evaluation of exopolysaccharides produced by marine isolated bacteria. Carbohydrate Polymers 87, 846-852. doi: 10.1016/j.carbpol.2011.08.085

Hoseinifar, S.H., Sun, Y-Z., Wang, A. and Zhou, Z. (2018). Probiotic as means of diseases control in aquaculture, a review of current knowledge and future perspectives. Frontiers in Microbiology 9, 2429. doi: 10.3389/fmib.2018.02429

Hoseinifar, S.H., Dadar, M., van Doan, H. and Harikrishnan, R. (2019). "Feed additives impacts on shellfish microbiota, health, and development" in Microbial Communities in Aquaculture Ecosystems, ed N. Derome (Switzerland: Springer Nature), 143-163. doi:10.1007/978-3-030-16190-3_7

Hou, D., Huang, Z., Zeng, S., Liu, J., Weng, S. and He, J (2018). Comparative analysis of the bacterial community compositions of the shrimp intestine, surrounding water and sediments. Journal of Applied Microbiology 125, 792-799. doi: 10.1111/jam.13919

Huang, Z., Li, X., Wang, L. and Shao, Z. (2016). Changes in the intestinal bacterial community during the growth of white shrimp, Litopenaeus vannamei. Aquaculture Research 47, 1737-1746. doi: 10.1111/are.12628

Huynh, T-G., Hu, S-Y., Chiu, C-S., Truong, Q-P. and Liu, C-H (2019). Bacterial population in intestines of white shrimp, Litopenaeus vannamei fed a synbiotic containing Lactobacillus plantarum and galactooligosaccharide. Aquaculture Research doi: 10.1111/are.13951

Ibrahem, M.D. (2015). Evolution of probiotics in aquatic world: Potential effects, the current status in Egypt and recent prospectives. Journal of Advanced Research 6, 765-791. doi: 10.1016/j.jare.2013.12.004 
Ige, M. A. (2013). Probiotics use in intensive fish farming. African Journal of Microbiology Research 7, 2701-2711. doi: 10.5897/AJMRx12.021

Irianto, A., and Austin, B. (2002a). Probiotics in aquaculture. Journal of Fish Diseases, 25, 633-642. doi: 10.1046/j.1365-2761.2002.00422.x

Irianto, A., and Austin, B. (2002b). Use of probiotics to control furunculosis in rainbow trout, Oncorhynchus mykiss (Walbaum). Journal of Fish Diseases 25, 333-342. doi: 10.1046/j.1365-2761.2002.00375.x

Kaisho, T. and Akira, S. (2004). Pleiotropic function of toll-like receptors. Microbes and Infection 6, 1388-1394. doi: 10.1016/j.micinf.2004.08.019

Kamarudin, M.S., Jones, D.A., Le Vay, L., and Abidin, A.Z. (1994). Ontogenetic change in digestive enzyme activity during larval development of Macrobrachium rosenbergii. Aquaculture 123, 323-333. doi: 10.1016/0044-8486(94)90068-X

Kanmani, P., Kumar, R.S., Yuvaraj, N., Paari, K.A., Puttukumar, V. and Arul, V. (2010). First identification of a novel probiotic bacterium Streptococcus phocae PI80 and its beneficial role in diseases control. Journal of International Dental and Medical Research 3, 45-51.

Kanmani, P., Kumar, R.S., Yuvaraj, N., Paari, K.A., Puttukumar, V. and Arul, V. (2011). Production and purification of a novel exopolysaccharide from lactic acid bacterium Streptococcus phocae PI80 and its functional characteristics activity in vitro. Bioresource Technology 102, 4827-4833. doi: 10.1016/j.biotech.2010.12.118

Kang, C-H., Shin, Y.J., Kim, Y.G. and So, J-S. (2016). Isolation of Lactobacillus strains from shellfish and their potential use as probiotics. Biotechnology and Bioprocess Engineering 21, 46-52. doi: 10.1007/s12257-015-0518-X

Katya, K., Yun, Y.-H., Park, G., Lee, J.-Y., Yoo, G., and Bai, S.C. (2014). Evaluation of the efficacy of fermented by-product of mushroom, Pleurotus ostreatus, as a fish meal replacer in juvenile amur catfish, Silurus asotus: Effects on growth, serological characteristics and immune responses. Asian-Australasian Journal of Animal Sciences 27, 1478-1486. doi: 10.5713/ajas.2014.14038

Kennedy, B., Venugopal, M.N., Karunasagar, I. and Karunasagar, I. (2006). Bacterial flora associated with the giant freshwater prawn Macrobrachium rosenbergii, in the hatchery system. Aquaculture 261, 1156-1167. doi: 10.1016/j.aquaculture. 2006.09.015

Kennedy, D.A., Kurath, G., Brito, I.L., Purcell, M.K., Read, A.F., Winton, J.R., et al. (2016). Potential drivers of virulence evolution in aquaculture. Evolutionary Applications 9, 344354. doi: 10.1111/eva.12342

Kesarcodi-Watson, A., Kaspar, H., Lategan, M.J., and Gibson, L. (2008). Probiotics in aquaculture: The need, principles and mechanisms of action and screening processes. Aquaculture 274, 1-14. doi: 10.1016/j.aquaculture.2007.11.019

Kim, D., Beck, B. R., Heo, S. B., Kim, J. J., Kim, H. D., Lee, S. M., et al. (2013). Lactococcus lactis BFE920 activates the innate immune system of olive flounder (Paralichthys olivaceus), resulting in protection against Streptococcus iniae infection and enhancing feed efficiency and weight gain in large-scale field studies. Fish \& Shellfish Immunology 35, 1585-1590. doi: 10.1016/j.fsi.2013.09.008 
Kim, D., Beck, B. R., Lee, S. M., Jeon, J. S., Lee, D. W., Lee, J I., et al. (2016). Pellet feed adsorbed with the recombinant Lactococcus lactis BFE920 expressing SiMA antigen induced strong recall vaccine effects against Streptococcus iniae infection in olive flounder (Paralichthys olivaceus). Fish \& Shellfish Immunology 55, 374-383. doi: 10.1016/j.fsi.2016.06.010

Kim, S., Lee, M-J., Lee, J-J., Choi, S.H. and Kim, B-S. (2017) Analysis of microbiota of the swimming crab (Portunus trituberculatus) in South Korea to identify risk markers for foodborne illness. LWT - Food Science and Technology 86, 483-491. doi: 10.1016/j.lwt.2017.08.043

Kimbrell, D. A. and Beutler, B. (2001). The evolution and genetics of innate immunity. Nature Reviews Genetics 2, 256-267. doi: 10.1038/35066006

Kiss, T. (2010). Apoptosis and its functional significance in molluscs. Apoptosis 15, 313-321. doi: 10.1007/s10495-009-0446-3

Kongnum, K. and Hongpattarakere, T. (2012). Effect of Lactobacillus plantarum isolated from digestive tract of wild shrimp on growth and survival of white shrimp (Litopenaeus vannamei) challenged with Vibrio harveyi. Fish \& Shellfish Immunology 32, 170-177. doi: 10.1016/j.fsi.2011.11.008

Kosin, B. and Rakshit, S.K. (2010). Induction of heat tolerance in autochthonous and allochthonous probiotics for application to white shrimp feed. Aquaculture 306, 302-309. doi: 10.1016/j.aquaculture.2010.04.017

Kullisaar, T., Zilmer, M., Mikelsaar, M., Vihalemm, T., Annuk, H., Kairane, C., and Kilk, A. (2002). Two antioxidative Lactobacilli strains as promising probiotics. International Journal of Food Microbiology 72, 215-224. doi: 10.1016/S0168-1605(01)00674-2

Kumar, V., Roy, S., Meena, D.K. and Sarkar, U.K. (2016). Application of probiotics in shrimp aquaculture: Importance, mechanisms of action, and methods of administration. Reviews in Fisheries Science \& Aquaculture 24, 342-368. doi: 10.1080/23308249.2016.1193481

Kurtz, J. and Armitag, S. A. O. (2006). Alternative adaptive immunity in invertebrates. Trends in Immunology 27, 493-496. doi: 10.1016/j.it.2006.09.001

Lalitha, K.V. and Surendran, P.K. (2004). Bacterial microflora associated with farmed freshwater prawn Macrobrachium rosenbergii (de Man) and the aquaculture environment. Aquaculture Research 35, 629-635. doi:10.1111/j.1365-2109.2004.01039

Lauriano, E.R., Pergolizzi, S., Capillo, G., Kuciel, M., Alesci, A., and Faggio, C. (2016). Immunohistochemical characterization of Toll-like receptor 2 in gut epithelial cells and macrophages of goldfish Carassius auratus fed with a high-cholesterol diet. Fish \& Shellfish Immunology 59, 250-255. doi: 10.1016/j.fsi.2016.11.003

Lee, S. Y. and Söderhäll, K. (2002). Early events in crustacean innate immunity. Fish \& Shellfish Immunology 12, 421-437. doi: 10.1006/fsim.2002.0420 
Lesser, M.P. (2006). Oxidative stress in marine environments: Biochemistry and pysiological ecology. Annual Review of Physiology 68, 253-278. doi: 10.1146/annurev.physiol.68.040104.110001

Leyva-Madrigal, K.Y., Luna-Gonzalez, A., Escobedo-Bonilla, C.M., Fierro-Coronado, J.A. and Maldonado-Mendoza, I.E. (2011). Screening for potential probiotic bacteria to reduce prevalence of WSSV and IHHNV in whiteleg shrimp (Litopenaeus vannamei) under experimental conditions. Aquaculture 322-323, 16-22. doi: 10.1016/j.aquaculture. 2011.09.033

Li, K., Guan, W., Wei, G., Liu, B., Xu, J., Zhao, L., et al. (2007). Phylogenetic analysis of intestinal bacteria in the Chinese mitten crab (Eriocheir sinensis). Journal of Applied Microbiology 103, 675-682. doi: 10.1111/j.1365-2672.2007.03295.x

Li, S., Sun, L., Wu, H., Hu, Z., Liu, W., Li, Y. and Wen, X. (2012). The intestinal microbial diversity in mud crab (Scylla paramamosain) as determined by PCR-DGGE and clone library analysis. Journal of Applied Microbiology 113, 1341-1351. doi:1111/jam.12008

Li, F. and Xiang, J. (2013). Signalling pathways regulating innate immune responses in shrimp. Fish \& Shellfish Immunology 34, 973-980. doi: 10.1016/j.fsi.2012.08.023

Li, E., Xu, C., Wang, X., Wang, S., Zhao, Q., Zhang, M., et al. (2018a) Gut microbiota and its modulation for healthy farming of Pacific white shrimp Litopenaeus vannamei. Reviews in Fisheries Science \& Aquaculture 26, 381-399. doi: 10.1080/23308249.2018.1440530

Li, X., Ring $\varnothing$, E., Hoseinifar, S.H., Lauzon, H., Birkbeck, H., and Yang, D. (2018b). Adherence and colonisation of microorganisms in the fish gastrointestinal tract. Rev Aquacult. doi: 10.1111/raq. 12248

Liu, H., Wang, L., Liu, M., Wang, B., Jiang, K., Ma, S. and Li, Q. (2011). The intestinal microbial diversity in Chinese shrimp (Fenneropenaeus chinensis) as determined by PCRDGGE and clone library analyses. Aquaculture 317, 32-36. doi: 10.1016/j.aquaculture. 2011.04.008

Loker, E. S., Adema, C. M., Zhang, S. M. and Kepler, T. B. (2004). Invertebrate immune systems - not homogeneous, not simple, not well understood. Immunological Reviews 198, 10-24. doi: 10.1111/j.0105-2896.2004.0117.x

Lovett, D.L., and Felder, D.L. (1990). Ontogenetic change in digestive enzyme activity of larval and postlarval white shrimp Penaeus setiferus (Crustacea, Decapoda, Penaeidae). The Biological Bulletin 178, 144-159. doi: 10.2307/1541973

Lu, G., Wang, F., Yu, Z., Lu, M., Wang, Y., Liu, C., et al. (2017) Bacterial communities in gills and intestines of yesso scallop (Patinopecten yessoensis) and its habitat waters in Changhai (Dalian, China). ISJ 14, 340-351.

Lushchak, V.I. (2011). Environmentally induced oxidative stress in aquatic animals. Aquatic Toxicology 101, 13-30. doi: 10.1016/j.aquatox.2010.10.006

Ma, C.-W., Cho, Y.-S., and Oh, K.-H. (2009). Removal of pathogenic bacteria and nitrogens by Lactobacillus spp. JK-8 and JK-11. Aquaculture 287, 266-270. doi: 10.1016/j.aquaculture.2008.10.061

Maeda, M., Shibata, A., Biswas, G., Korenga, H., Kono, T., Itami, T., et al. (2014). Isolation of lactic acid bacteria from Kuruma shrimp (Marsupenaeus japonicus) intestine and assessment of immunomodulatory role of a selected strain as probiotic. Marine Biotechnology 16, 181-192. doi: 10.1007/s10126-013-95352-1 
Magnadóttir, B. (2006). Innate immunity of fish (overview). Fish \& Shellfish Immunology 20, 137-151. doi: 10.1016/j.fsi.2004.09.006

Martínez Cruz, P., Ibáñez, A.L., Monroy Hermosillo, O.A., and Ramírez Saad, H.C. (2012). Use of probiotics in aquaculture. ISRN Microbiology 2012, 916845. doi: $10.5402 / 2012 / 916845$

McFall-Ngai, M. (2007). Care for the community. Nature 445, 153. doi: 10.1038/445153a

Menze, M. A., Fortner, G., Nag, S. and Hand, S. C. (2010). Mechanisms of apoptosis in crustacean: what conditions induce versus suppress cell death? Apoptosis 15, 293-312. doi: 10.1007/s10495-009-0443-6

Merrifield, D. L., Balcázar J. L., Daniels C., Zhou Z., Carnevali O., Sun Y. Z., et al. (2014). "Indigenous lactic acid bacteria in fish and crustaceans" in Aquaculture Nutrition: Gut Health, Probiotics and Prebiotics, eds D. Merrifield and E. Ring (Oxford, UK: WileyBlackwell Publishing), 128-168. doi: 10.1002/9781118897263.ch6

Meziti, A., Ramette, A., Mente, E. and Kormas, K.A. (2010). Temporal shifts of the Norway lobster (Nephrops norvegicus) gut bacterial communities. FEMS Microbial Ecology 74, 472-484. doi: 10.1111/j.1574-6941.2010.00964.x

Miranda, C.D., Godoy, F.A., and Lee, M.R. (2018). Current status of the use of antibiotics and the antimicrobial resistance in the Chilean salmon farms. Frontiers in Microbiology 9, 1284. doi: 10.3389/fmicb.2018.01284

Miandare, H.K., Yarahmadi, P. and Abbasian, M. (2016). Immune related transcriptional responses and performance of Litopenaeus vannamei post-larvae fed on dietary probiotic PrimaLac ${ }^{\circ}$. Fish \& Shellfish Immunology 55, 671-678. doi: 10.1016/j.fsi.2016.06.053

Mongkol, P., Bunphimpapha, P., Rungrassamee, W., Arayamethakorn, S., Klinbunga, S., Menasveta, P., et al. (2018) Bacterial community composition and distribution in different segments of the gastrointestinal tract of wild-caught adult Penaeus monodon. Aquaculture Research 49, 378-392- doi: 10.1111/are.13468

Moriarty, D.J.W. (1998). Control of luminous Vibrio species in penaeid aquaculture ponds. Aquaculture 164, 351-358. doi: 10.1016/S0044-8486(98)00199-9

Muhlia-Almazán, A., García-Carreño, F.L., Sánchez-Paz, J.A., Yepiz-Plascencia, G., and Peregrino-Uriarte, A.B. (2003). Effects of dietary protein on the activity and mRNA level of trypsin in the midgut gland of the white shrimp Penaeus vannamei. Comparative Biochemistry and Physiology - B Biochemistry and Molecular Biology 135, 373-383. doi: 10.1016/S1096-4959(03)00091-5

Nath, S., Matozzo, V., Bhandari, D., and Faggio, C. (2018). Growth and liver histology of Channa punctatus exposed to a common biofertilizer. Natural Product Research 33, 15911598. doi: 10.1080/14786419.2018.1428586

Nava-Hernández, J.C. (2008). Efecto de lactobacilos y bacilos con potential probiótico, en el crecimiento y supervivencida de larvas y semillas de Nodipecten subnodosus (Sowerby, 
1985) y Crassostrea corteziensis (Hertlein, 1951), cultivados en el laboratorio. Master thesis, Universidad Autónoma de Baja California Sur, La Paz, México.

Nedaei, S., Noori, A., Valipour, A., Khanipoir, A.A. and Hoseinifar, S.H. (2019). Effects of dietary galactooligosaccharide enriched commercial prebiotic on growth performance, innate immune response, stress resistance, intestinal microbiota and digestive enzyme activity in Narrow clawed crayfish (Astacus leptodactylus Eschscholtz, 1823). Aquaculture 499, 80-89. doi: 10.1016/j.aquaculture.2018.08.076

Nimrat, S., Tanutpongpalin, P., Sritunyalucksana, K., Boonthai, T. and Vuthiphandchai, V. (2013). Enhancement of growth performance, digestive enzyme activities and disease resistance in black tiger shrimp (Penaeus monodon) postlarvae by potential probiotics. Aquaculture International 21, 655-666. doi: 10.1007/s10499-012-9600-y

Ninawe, A.S. and Selvin, J. (2009). Probiotics in shrimp aquaculture: Avenues and challenges. Critical Reviews in Microbiology 35, 43-66. doi: 10.1080/10408410802667202

Nonaka, M. and Yoshizaki, F. (2004). Primitive complement system of invertebrates. Immunological Reviews 198, 203-215. doi: 10.1111/j.0105-2896.2004.00118.x

Ooi, M.C., Goulden, E.F., Smith, G.G., Nowak, B.F. and Bridle, A.R. (2017). Developmental and gut-related changes to microbiomes of cultured juvenile spiny lobster Panulirus ornatus. FEMS Microbiology Ecology 93, fix 159. doi: 10.1093/femsec/fix159.

Pacheco-Vega, J.M., Cadena-Roa, M.A., Leyva-Flores, J.A., Zavala-Leal, O.I., Pérez-Bravo, E., and Ruiz-Velazco, J.M.J. (2018). Effect of isolated bacteria and microalgae on the biofloc characteristics in the Pacific white shrimp culture. Aquaculture Reports 11, 24-30. doi: 10.1016/j.aqrep.2018.05.003

Panigrahi, A., Sundaram, M., Saranya, C., Swain, S., Dash, R.R. and Dayal, J.S. (2019). Carbohydrate sources deferentially influence growth performances, microbial dynamics and immunomodulation in Pacific white shrimp (Litopenaeus vannamei) under biofloc system. Fish \& Shellfish Immunology 86, 1207-1216. doi: 10.1016/j.fsi.2018.12.040

Pasquier, L. D. (2001). The immune system of invertebrates and vertebrates. Comparative Biochemistry and Physiology Part B 129, 1-15. doi: 10.1016/S1096-4959(01)00306-2

Pattukumar, V., Kanmani, P., Satish Kumar, R., Yuvaraj, N., Paari, A. and Arul, V. (2014) Enhancement of innate immune system, survival and yield in Penaeus monodon reared in ponds using Streptococcus phocae PI80. Aquaculture Nutrition 20, 505-513. doi: 10.1111/anu.12103

Pei, P., Liu, X., Chen, Y., Wu, J., Zhong, M., Lin, Q., et al. (2019) Effects of biological water purification grid on microbial community of culture environment and intestine of the shrimp Litopenaeus vannamei. Aquaculture Research doi: 10.1111/are.14006

Pinoargote, G., Flores, G., Cooper, K. and Ravishankar, S. (2018). Effects on survival and bacterial community composition of the aquaculture water and gastrointestinal tract of shrimp (Litopenaeus vannamei) exposed to probiotic treatments after an induced infection 
of acute hepatopancreatic necrosis disease. Aquaculture Research 49, 3270-3288. doi: 10.1111/are. 13791

Prieur, D., Mevel, G., Nicolas, J.L., Plusquellec, A., and Vigneulle, M. (1990). Interactions between bivalve molluscs and bacteria in the marine environment. Oceanography and Marine Biology 28, 277-352.

Qiao, F., Liu, Y.K., Sun, Y.H., Wang, X.D., Chen, K., Li, T.Y., et al. (2017). Influence of different dietary carbohydrate sources on the growth and intestinal microbiota of Litopenaeus vannamei at low salinity. Aquaculture Nutrition 23, 444-452. doi: 10.1111/anu.12412

Rao, V. (2007). Bioremediation to restore the health of aquaculture pond ecosystem. Advances in Aquatic Ecology 1, 85-94.

Rast, J., Smith, L. C., Loza-Co, M., Hibino, T. and Litman, G. W. (2006). Genomic insights into the immune system of the sea urchin. Science 314, 952-956. doi: $10.1126 /$ science. 1134301

Ray, A.K., Ghosh, K., and Ring $\varnothing$, E. (2012). Enzyme-producing bacteria isolated from fish gut: a review. Aquaculture Nutrition 18, 465-492. doi: 10.1111/j.1365-2095.2012.00943.x

Reverter, M., Tapissier-Bontemps, N., Sasal, P., and Saulnier, D. (2017). "Use of medicinal plants in aquaculture," in Diagnosis and Control of Diseases of Fish and Shellfish, eds. B. Austin and A. Newaj-Fyzul (Wiley Online Library), 221-261.

Ring $\varnothing$, E., Olsen, R. E., Vecino J. L. G., Wadsworth, S. and Song, S. K. (2012). Use of immunostimulants and nucleotides in aquaculture: a review. Journal of Marine Science: Research and Development 2, 1-22. doi: 10.4172/2155-9910.1000104

Ringø, E., Zhou, Z., Gonzalez Vecino, J.L., Wadsworth, S., Romero, J., Krogdahl, Å., et al. (2016). Effects of dietary components on the gut microbiota of aquatic animals: a neverending story? Aquaculture Nutrition 22, 219-282. doi: 10.1111/anu12346.

Ring $\varnothing$, E., Hoseinifar, S.H., Ghosh, K., Van Doan, H., Beck, B.R. and Song, S.K. (2018). Lactic acid bacteria in finfish - an update. Frontiers in Microbiology 9, 1818. doi: 10.3389/fmib.2018.01818

Romero, J., Ringø, E. and Merrifield, D.L. (2014). "The gut microbiota of fish" in Aquaculture Nutrition: Gut Health, Probiotics and Prebiotics, eds D. Merrifield and E. Ring (Oxford, UK: Wiley-Blackwell Publishing), 75-100. doi: 10.1002/9781118897263.ch4

Romo, M. R., Pérez-Martínez, D. and Ferrer, C. C. (2015). Innate immunity in vertebrates: an overview. Immunology 148, 125-139. doi: 10.1111/imm.12597

Roomiani, L., Ahmadi, S. and Ghaeni, M. (2018). Immune response and disease resistance in the white shrimp, Litopenaeus vannamei induced by potential probiotic Lactobacillus bulgaricus. Ankara Üniversitesi Veteriner Fakultesi Dergis 65, 323-329.

Rottmann, R., Francis-Floyd, R., and Durborow, R. (1992). The role of stress in fish disease. Southern Regional Aquaculture Center Stoneville, MS. 
Rungrassamee, W., Klanchui, A., Maibunkaew, S., Chaiyapechara, S., Jiravanichpaisal, P. and Karoonuthaisiri, N. (2014). Characterization of intestinal bacteria in wild and domesticated adult black tiger shrimp (Penaeus monodon). PLoS ONE 9, e91853. doi: 10.1371/journal.pone.0091853

Safari, O. and Paolucci, M. (2017) Modulation of growth performance, immunity, and disease resistance in narrow-clawed crayfish, Astacus leptodactylus leptodactylus (Eschscholtz, 1823) upon synbiotic feeding. Aquaculture 479, 333-341. doi. 10.1016/j.aquaculture.2017.05.049

Salzet, M. (2001). Vertebrate innate immunity resembles a mosaic of invertebrate immune responses. Trends in Immunology 22, 285-288. doi: 10.1016/S1471-4906(01)01895-6

Sánchez-Salgado, J. L., Pereyra, M. A., Agundis, C., Vivanco-Rojas, O., Sierra-Castillo, C., Alpuche-Osorno, J. J., et al. (2017). Participation of lectin in crustacean immune system. Aquaculture Research 48, 4001-4011. doi: 10.1111/are.13394

Sarkono, S., Rahman, F. and Sofyan, Y. (2010) Isolation and identification of lactic acid bacteria from abalone (Haliotis asinina) as potential candidate of probiotic. Bioscience 2, $38-42$.

Santos, L., and Ramos, F. (2018). Antimicrobial resistance in aquaculture: Current knowledge and alternatives to tackle the problem. International Journal of Antimicrobial Agents 52, 135-143. doi: 10.1016/j.ijantimicag.2018.03.010

Selye, H. (1982). Stress: Eustress, distress, and human perspectives. Life stress 3.

Seenivasan, C., Radhakrishnan, S., Shanthi, R., Muralisankar, T. and Saravana Bhavan, P. (2014). Effect of Lactobacillus sporogenes on survival, growth, biochemical constituents and energy utilization of freshwater prawn Macrobrachium rosenbergii post larvae. The Journal of Basic \& Applied Zoology 67, 19-24. doi: 10.1016/j.jobaz.2013.12.002

Seghouani, H., Garcia-Rangel, C.-E., Füller, J., Gauthier, J., and Derome, N. (2017). Walleye autochthonous bacteria as promising probiotic candidates against Flavobacterium columnare. Frontiers in Microbiology 8, 1349. doi: 10.3389/fmicb.2017.01349

Serra, C.R., Almeida, E.M., Guerreiro, I., Santos, R., Merrifield, D.L., Tavares, F., et al. (2019). Selection of carbohydrate-active probiotics from the gut of carnivorous fish fed plant-based diets. Scientific Reports 9, 6384. doi: 10.1038/s41598-019-42716-7

Sha, Y., Wang, B., Liu, M., Jiang, K. and Wang, B. (2016a). Interaction between Lactobacillus pentosus $\mathrm{HC}-2$ and Vibrio parahaemolyticus $\mathrm{E} 1$ in Litopenaeus vannamei in vivo and in vitro. Aquaculture 465, 117-123. doi: 10.1016/j.aquaculture.2016.09.007

Sha, Y., Wang, L., Liu, M., Jiang, K., Xin, F. and Wang, B. (2016b). Effects of lactic acid bacteria and the corresponding supernatant on the survival, growth performance, immune response and disease resistance of Litopenaeus vannamei. Aquaculture 452, 28-36. doi: 10.1016/j.aquaculture.2015.10.014

Sha, Y., Liu, M., Wang, B., Jiang, K., Qi, C. and Wang, L. (2016c). Bacterial population in intestine of Litopenaeus vannamei fed different probiotics or probiotic supernatant. Journal of Microbiology and Biotechnology 26, 1739-1745. doi: 10.4014/jmb.1603.03078

Silva, E.F., Soares, M.A., Calazans, N.F., Vogeley, J.L., Do Valle, B.C., Soares, R., and Peixoto, S. (2012). Effect of probiotic (Bacillus spp.) addition during larvae and postlarvae culture of the white shrimp Litopenaeus vannamei. Aquaculture Research 44, 13-21. doi: 10.1111/j.1365-2109.2011.03001.x 
Sivakumar, N., Sundararaman, M., and Selvakumar, G. (2012). Probiotic effect of Lactobacillus acidophilus against vibriosis in juvenile shrimp (Penaeus monodon). African Journal of Biotechnology 11, 15811-15818. doi: 10.5897/AJB12.1328

Smith, L. C., Arriza, V., Hudgell, M. A. B., Barone, G., Bodnar, A. G., Buckley, K. M., et al. (2018). "Echinodermata: the complex immune system in echinoderms" in Advances in Comparative Immunology, ed E.L. Cooper (Cham, Switzerland), 409-501. doi: 10.1007/978-3-319-76768-0_13

Smith, L. C., Ghos,h J., Buckley, K. M., Clow, L. A., Dheilly, N. M., Haug, T., et al. (2010). Echinoderm immunity. Advances in Experimental Medicine and Biology, 708, 260-301. doi: 10.1007/978-1-4419-8059-5_14

Sokolova, I. M. (2009). Apoptosis in molluscan immune defense. Invertebrate Survival Journal $6,49-58$.

Song, L., Wang, L., Qiu, L. and Zhang, H. (2010). Bivalve immunity. Advances in Experimental Medicine and Biology 708, 44-65. doi: 10.1007/978-1-4419-8059-5_3

Song, L., Wang, L., Zhang, H. and Wang, M. (2015). The immune system and its modulation mechanism in scallop. Fish \& Shellfish Immunology 46, 65-78. doi: 10.1016/j.fsi.2015.03.013

Sritunyalucksana, K. and Söderhäll, K. (2000). The proPO and clotting system in crustaceans. Aquaculture 191, 53-69. doi: 10.1016/S0044-8486(00)00411-7

Söderhäll, K. and Cerenius, L. (1998). Role of the prophenoloxidase-activating system in invertebrate immunity. Current Opinion in Immunology 10, 23-28. doi: 10.1016/S09527915(98)80026-5

Sun, Z., Xuan, Y., Zhang, H., Jiang, M., Pan, Y., Zhang, Y., et al. (2016). Bacterial diversity in the Penaeus vannamei Boone intestine and aquaculture environment. Journal of Fishery Sciences of China 23, 594-605. In Chinese with English abstract. doi: 10.3724/SP.J.1118.2016.15255

Suo, Y., Li, E., Li, T., Jia, Y., Qin, J.G., Gu, Z., et al. (2017). Response of gut health and microbiota to sulfide exposure in Pacific white shrimp Litopenaeus vannamei. Fish \& Shellfish Immunology 63, 87-96. doi: 10.1016/j.fsi.2017.02.008.

Sun, P., Jin, M., Ding, L., Lu, Y., Ma, H., Yuan, Y., et al. (2018). Dietary lipid levels could improve growth and intestinal microbiota of juvenile swimming crab, Portunus trituberculatus. Aquaculture 490, 208-216. doi: 10.1016/j.aquaculture.2018.02.018

Swain, S.M., Singh, C., and Arul, V. (2009). Inhibitory activity of probiotics Streptococcus phocae PI80 and Enterococcus faecium MC13 against vibriosis in shrimp Penaeus monodon. World Journal of Microbiology and Biotechnology 25, 697-703. doi: 10.1007/s11274-008-9939-4

Talpur, A.D., Memon, A.J., Khan, M.I., Ikhwanuddin, M., Danish Daniel, M.M. and AbolMunafi, A.B. (2012). Isolation and screening of lactic acid bacteria from the gut of blue swimming crab, $P$. pelagicus, and in vitro inhibition assay and small scale in vivo model 
for validation of isolates as probiotics. Journal of Fisheries and Aquatic Science 7, 1-28. doi: 10.3923/jfas.2012.1.28

Talpur, A. D., Ikhwanuddin, M., Abdullah, M. D. D. and Bolong, A. M. A. (2013). Indigenous Lactobacillus plantarum as probiotic for larviculture of blue swimming crab, Portunus pelagicus (Linnaeus, 1758): Effects on survival, digestive enzyme activities and water quality. Aquaculture 416-417, 173-178. doi: 10.1016/j.aquaculture.2013.09.018

Tort, L., Balasch, J. C. and Mackenzie, S. (2003). Fish immune system. A crossroads between innate and adaptive responses. Immunologia 22, 277-286.

Tovar, D., Zambonino, J., Cahu, C., Gatesoupe, F., Vázquez-Juárez, R., and Lésel, R. (2002). Effect of live yeast incorporation in compound diet on digestive enzyme activity in sea bass (Dicentrarchus labrax) larvae. Aquaculture 204, 113-123. doi: 10.1016/S00448486(01)00650-0

Tripp, M. R. (1974). Molluscan immunity. Annals of the New York Academy of Sciences 234, 23-27. doi: 10.1111/j.1749-6632.1974.tb53016.x

Tysset, C., Mailloux, M. and Brisou, J. (1961) La microflore commensale de la crevette rouge des côtes Algériennes. Archives Dellnstitut Pasteur DAlgeriere 39, 287-301.

Tzeng, T-D., Pao, Y-Y., Chen, P-C., Weng, FC-H., Jean, W.D, and Wang, D. (2015). Effects of host phylogeny and habitats on gut microbiomes of Oriental river prawn (Macrobrachium nipponense). PLoS ONE 10: e0132860. doi: 10.1371/journal.pone.0132860

Uaboi-Egbenni, P.O., Okolie, P.N., Famuyiwa, O. and Teniola, O. (2010). The significance of pathogenic bacteria in the gut of swimming crab, Callinectes sp. obtained from Lagos lagoon and market samples stored at freezer temperature $\left(0^{\circ} \mathrm{C}\right)$. Pakistan Journal of Nutrition 9, 398-403.

van Hai, N. and Fotedar, R. (2010). A review of probiotics in shrimp aquaculture. Journal of Applied Aquaculture 22, 251-266. doi: 10.1980/10454438.2010.500597

Vasama, M., Kumar, H., Salminen, S. and Haskard, C. A. (2014). Removal of paralytic shellfish toxins by probiotic lactic acid bacteria. Toxins 6, 2127-2136. doi: 10.3390/toxins6072127

Vazquez, L., Alpuche, J., Maldonado, G., Agund,is C., Pereyra-Morales, A. and Zenteno, E. (2009). Immunity mechanisms in crustaceans. Innate Immunity 15, 179-188. doi: $10.1177 / 1753425909102876$

Verschuere, L., Rombaut, G., Sorgeloos, P., and Verstraete, W. (2000). Probiotic bacteria as biological control agents in aquaculture. Microbiology and Molecular Biology Reviews 64, 655-671. doi: 10.1128/MMBR.64.4.655-671.2000

Vieira, F.N., Pedrotti, F.S., Neto, C.C.B., Mouriño, J.L.P., Beltrame, E., Martins, M.L., et al. (2007). Lactic-acid bacteria increase the survival of marine shrimp, Litopenaeus vannamei, after infection with Vibrio harveyi. Brazilian Journal of Oceanography 55, 251-255.

Vieira, F.N., Neto, C.C.B., Mouriño, J.L.P., Jatobá, A., Ramirez, C., Martins, M.L., et al. (2008). Time-related action of Lactobacillus plantarum in the bacterial microbiota of 
shrimp digestive tract and its action as immunostimulants. Pesquisa Agropecuária Brasileira 43, 763-767. doi: 10.1590/S0100-204X2008000600013

Vieira, F.N., Buglione, C.C., Mouriño, J.L.P., Jatobá, A., Martins, M.L., Schleder, D.D., et al. (2010). Effect of probiotic supplemented diet on marine shrimp survival after challenge with Vibrio harveyi. Arquiva Brasilerio de Medicina Veterinária e Zootecnia 62, 631-638. doi: 10.1590/S0102-09352010000300019

Vijayabaskar, P. and Somasundaram, S.T. (2008). Isolation of bacteriocin producing lactic acid bacteria from fish gut and probiotic activity against common fresh water fish pathogen Aeromonas hydrophila. Biotechnology 7, 124-128. doi: 10.3923/biotech.2008.124.128

Vine, N.G., Leukes, W.D., and Kaiser, H. (2006). Probiotics in marine larviculture. FEMS Microbiology Reviews 30, 404-427. doi: 10.1111/j.1574-6976.2006.00017.x

Wang, X. W. and Wang, J. X. (2013). Pattern recognition receptors acting in innate immune system of shrimp against pathogen infections. Fish \& Shellfish Immunology 34, 981-989. doi: 10.1016/j.fsi.2012.08.008

Wang, Y.-B., Xu, Z.-R., and Xia, M.-S. (2005). The effectiveness of commercial probiotics in northern white shrimp Penaeus vannamei ponds. Fisheries Science 71, 1036-1041. doi: 10.1111/j.1444-2906.2005.01061.x

Wang, P.C., Lin, Y.D., Liaw, L.L., Chern, R.S. and Chen, S.C. (2008) Lactococcus lactis subsp. lactis causes white muscle disease in farmed giant freshwater prawns Macrobrachium rosenbergii. Diseases of Aquatic Organisms 79, 9-17. doi: 10.3354/dao01868

Wang, G., Huang, Y., Zhou, Y., Dong, S., Huang, W., and Yan, Q. (2010). Effects of Lactobacillus on growth performance, digestive enzyme activities and non-specific immunity of Litopenaeus vannamei [J]. Chinese Journal of Animal Nutrition 22, 228-234.

Wang, Y., Fu, L., and Lin, J. (2012). Probiotic (Bacillus coagulans) cells in the diet benefit the white shrimp Litopenaeus vannamei. Journal of Shellfish Research 31, 855-860. doi: $10.2983 / 035.031 .0333$

Wang, Y. C., Hu, S. Y., Chiu, C. S. and Liu, C. H. (2019). Multiple-strain probiotics appear to be more effective in improving the growth performance and health status of white shrimp, Litopenaeus vannamei, than single probiotic strains. Fish \& Shellfish Immunology 84, 1050-1058. doi: 10.1016/j.fsi.2018.11.017

Wanka, K.M., Damerau, T., Costas, B., Krueger, A., Schulz, C., and Wuertz, S. (2018). Isolation and characterization of native probiotics for fish farming. BMC Microbiology 18, 119. doi: 10.1186/s12866-018-1260-2

Watts, J.E.M., Schreier, H.J., Lanska, L., and Hale, M.S. (2017a). The rising tide of antimicrobial resistance in aquaculture: Sources, sinks and solutions. Marine Drugs 15, 158. doi: $10.3390 / \mathrm{md} 15060158$

Watts, J. E. M., Schreier, H. J., Lanska, L., \& Hale, M. S. (2017b). The rising tide of antimicrobial resistance in aquaculture: sources, sinks and solutions. Marine Drugs 15 (6)(158), 16. doi: 10.3390/md15060158

Wei, Y.F., Liao, S-A. and Wang, A-1. (2016). The effect of different carbon sources on the nutritional composition, microbial community and structures of bioflocs. Aquaculture 465, 88-93. doi: 10.1016/j.aquaculture.2016.08.040 
Xiong, J. (2018). Progress in the gut microbiota in exploring shrimp disease pathogenesis and incidence. Applied Microbiology and Biotechnology 102: 7343-7350. doi: 10.1007/s00253-018-9199-7

Xiong, J., Dai, W., Zhu, J., Liu, K., Dong, C. and Qiu, Q. (2017). The underlying ecological processes of gut microbiota among cohabitating retarded, overgrown and normal shrimp. Microbial Ecology 73, 988-999. doi: 10.1007/s00248-016-0910-x

Xue, M., Wu, L., He, Y., Liang, H. and Wen, C. (2018). Biases during DNA extraction affect characterization of the microbiota associated with larvae of the pacific white shrimp, Litopenaeus vannamei. PeerJ 6, e5257. doi: 10.7717/peerj.5257

Yeh, S.-T., Lin, Y.-C., Huang, C.-L., and Chen, J.-C. (2010). White shrimp Litopenaeus vannamei that received the hot-water extract of Gracilaria tenuistipitata showed protective innate immunity and up-regulation of gene expressions after low-salinity stress. Fish \& Shellfish Immunology 28, 887-894. doi: 10.1016/j.fsi.2010.02.005

Yeh, S. P., Chiu, C. H., Shiu, Y. L., Huang, Z. L. and Liu, C. H. (2014). Effects of diets supplemented with either individual or combined probiotics, Bacillus subtilis E20 and Lactobacillus plantarum 7-40, on the immune response and disease resistance of the mud crab, Scylla paramamosain (Estampador). Aquaculture Research 45, 1164-1175. doi: 10.1111/are.12061

Zhang, S. M., Adema, C. M., Kepler, T. B. and Loker, E. S. (2004). Diversification of Ig superfamily genes in an invertebrate. Science 305, 251-254. doi: 10.1126/science. 1088069

Zhang, M., Sun, Y., Chen, K., Yu, N., Zhou, Z., Chen, L., et al. (2014). Characterization of the intestinal microbiota in Pacific white shrimp, Litopenaeus vannamei, fed diets with different lipid sources. Aquaculture 434, 449-455. doi: 10.1016/j.aquaculture.2014.09.008

Zhang, M., Sun, Y., Chen, L., Cai, C., Qiao, F., Du, Z., et al. (2016). Symbiotic bacteria in gills and guts of Chinese mitten crab (Eriocheir sinensis) differ from the free-living bacteria in water. PLoS ONE 11, e0148135. doi: 10.1371/journal.pone.0148135

Zhao, Y., Duan C., Zhang, X-x., Chen, H., Ren, H., Yin, T., et al. (2017). Insight into the gut microbiota of freshwater shrimp and its associations with the surrounding microbiota and environmental factors. Journal of Microbiology and Biotechnology 28, 946-956. doi: 10.4014/jmb.1710.09070

Zeng, S., Huang, Z., Hou, D., Liu, J., Weng, S. and He, J. (2017). Composition, diversity and function of intestinal microbiota in pacific white shrimp (Litopenaeus vannamei) at different culture stages. PeerJ 5, e3986. doi: 10.7717/perj.3986

Zheng, C.N. and Wang, W. (2017). Effects of Lactobacillus pentosus on the growth performance, digestive enzyme and disease resistance of white shrimp, Litopenaeus vannamei (Boone, 1931). Aquaculture Research 48, 2767-2777. doi: 10.1111/are.13110

Zheng, X., Duan, Y., Dong, H., and Zhang, J. (2017). Effects of dietary Lactobacillus plantarum in different treatments on growth performance and immune gene expression of white shrimp Litopenaeus vannamei under normal condition and stress of acute low salinity. Fish \& Shellfish Immunology 62, 195-201. doi: 10.1016/j.fsi.2017.01.015

Zheng, X., Duan, Y., Dong, H. and Zhang, J. (2018). Effects of dietary Lactobacillus plantarum on growth performance, digestive enzymes and gut morphology of Litopenaeus vannamei. Probiotics \& Antimicrobial Proteins 10, 504-510. doi: 10.1007/s12602-017-9300-Z

Zhou, Z., Ding, Z. and Huiyuan, L.V. (2007). Effects of dietary short-chain fructooligosaccharides on intestinal microflora, survival, and growth performance of 
juvenile white shrimp, Litopenaeus vannamei. Journal of the World Aquaculture Society 38, 296-301. doi: 10.1111/j.1749-7345.2007.00099.x

Zhou, J., Wang, L., Xin, Y., Wang, W.N., He, W.Y., Wang, A.L., et al. (2010). Effect of temperature on antioxidant enzyme gene expression and stress protein response in white shrimp, Litopenaeus vannamei. Journal of Thermal Biology 35, 284-289. doi: 10.1016/j.jtherbio.2010.06.004

Zhou, Y., Cui, Y. and Qu, X. (2019). Exopolysaccharides of lactic acid bacteria: Structure, bioactivity and associations: A review. Carbohydrate Polymers 201, 317-332. doi: 10.1016/j.carbpol.2018.11.093

Ziaei-Nejad, S., Rezaei, M.H., Takami, G.A., Lovett, D.L., Mirvaghefi, A.-R., and Shakouri, M. (2006). The effect of Bacillus spp. bacteria used as probiotics on digestive enzyme activity, survival and growth in the Indian white shrimp Fenneropenaeus indicus. Aquaculture 252, 516-524. doi: 10.1016/j.aquaculture.2005.07.021

Zuo, Z.-H., Shang, B.-J., Shao, Y.-C., Li, W.-Y., and Sun, J.-S. (2019). Screening of intestinal probiotics and the effects of feeding probiotics on the growth, immune, digestive enzyme activity and intestinal flora of Litopenaeus vannamei. Fish \& Shellfish Immunology 86, 160-168. doi: 10.1016/j.fsi.2018.11.003 
1696 
Table 1. Lactic acid bacteria (LAB) in the gastrointestinal (GI) tract, hepatopancreas and in muscle of shellfish, detected by culture based or culture-independent methods (C-IM).

\begin{tabular}{|c|c|c|c|c|c|c|}
\hline Species & Source & $\begin{array}{l}\text { Isolated } \\
\text { from }\end{array}$ & Methodology & $\begin{array}{l}\text { Allo or } \\
\text { auto }\end{array}$ & LAB identified & References \\
\hline Shrimp* & Natural/wild & Gl tract & Cultivation & $\mathrm{ni}$ & Lb. plantarum ${ }^{2}$ & Hongpattarakere et al., 2012 \\
\hline \multirow{4}{*}{$\begin{array}{l}\text { Giant freshwater prawn } \\
\text { (Macrobrachium } \\
\text { rosenbergii) }\end{array}$} & Natural/wild & GI tract & Cultivation & Allo+auto & $\begin{array}{l}\text { Lac. garvieae, P. acidilactici and } \\
\text { E. faecium }\end{array}$ & Cai et al., $1999^{1}$ \\
\hline & Natural/wild & GI tract & Cultivation & Allo+auto & Enterococcus spp. & Lalitha and Surendran, 2004 \\
\hline & Natural/wild & GI tract & Cultivation & Allo+auto & Lactobacillus spp. & Kennedy et al., $2006^{1}$ \\
\hline & Aquaculture & GI tract & Cultivation & Allo+auto & Lactobacillus sp. & Dash et al., 2014, 2016 \\
\hline \multirow{3}{*}{$\begin{array}{l}\text { Oriental river prawn } \\
\text { (Macrobrachium } \\
\text { nipponense) }\end{array}$} & Natural/wild & GI tract & C-IM & Allo+auto & $\begin{array}{l}\text { Lactobacillus sp., Leuconostoc sp. and } \\
\text { Streptococcus sp. }\end{array}$ & Tzeng et al., 2015 \\
\hline & Natural/wild & GI tract & C-IM & Allo+auto & Latobacillales* and Enterococcaceae* & Chen et al., 2017a \\
\hline & Natural/wild & $\begin{array}{l}\text { GI tract } \\
\text { content }\end{array}$ & C-IM & Allo & $\begin{array}{l}\text { Lactobacillus sp., Lactococcus sp., } \\
\text { Leuconostoc sp., Carnobacteriaceae*, } \\
\text { Aerococcaceae* and Enterococcaceae* }\end{array}$ & Zhao et al., 2018 \\
\hline $\begin{array}{l}\text { Pacific white shrimp } \\
\text { (Litopenaeus vannamei) }\end{array}$ & Aquaculture & GI tract & Cultivation & Allo+auto & LAB* & Viera et al., $2007^{1}$ \\
\hline
\end{tabular}




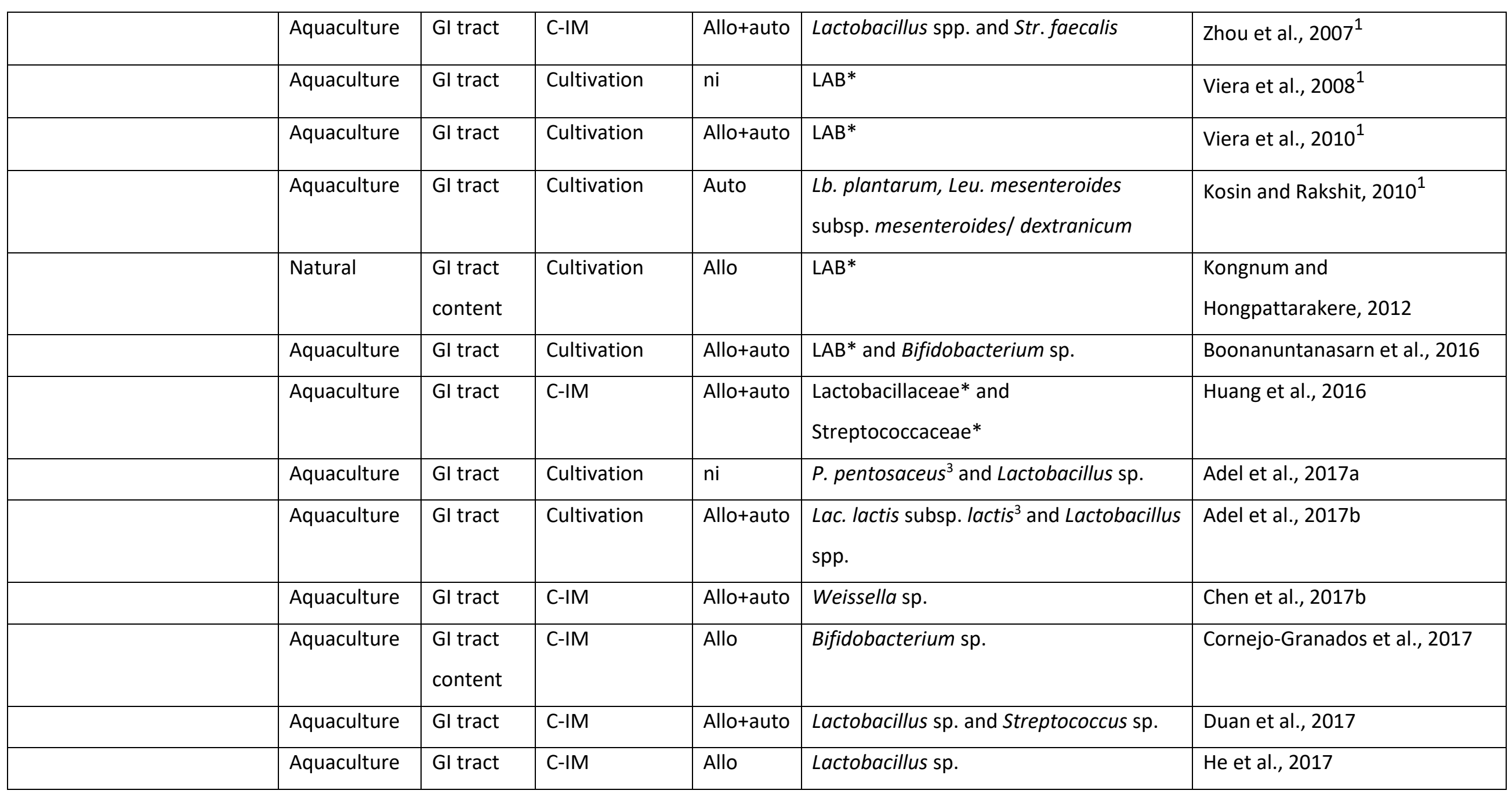




\begin{tabular}{|c|c|c|c|c|c|c|}
\hline & Aquaculture & $\begin{array}{l}\text { Gut } \\
\text { content }\end{array}$ & C-IM & Allo & $\begin{array}{l}\text { Carnobacterium sp., Lactococcus sp., } \\
\text { Lactobacillus sp., Leuconostoc sp., and } \\
\text { Streptococcus sp. }\end{array}$ & Suo et al., 2017 \\
\hline & Aquaculture & Gl tract & C-IM & Allo+auto & Lactobacillaceae* & Xiong et al., 2017 \\
\hline & Aquaculture & Gl tract & C-IM & Allo+auto & Lactobacillus sp. & Zeng et al., 2017 \\
\hline & Aquaculture & GI tract & Cultivation & ni & LAB and $L b$. pentosus ${ }^{3}$ & Zheng and Wang, 2017 \\
\hline & Aquaculture & $\begin{array}{l}\text { El with } \\
\text { content }\end{array}$ & Cultivation & Allo+auto & Lb. plantarum and Lac. lactis & Chomwong et al., 2018 \\
\hline & Aquaculture & Gl tract & C-IM & Allo+auto & Lactobacillus sp. and Lactococcus sp. & Duan et al., 2018 \\
\hline & Aquaculture & GI tract & C-IM & Allo+auto & Lactobacillus sp. and Streptococcus sp. & Hou et al., 2018 \\
\hline & Aquaculture & GI tract & C-IM & Auto & Lb. plantarum & Huynh et al., 2019 \\
\hline & Aquaculture & $\begin{array}{l}\text { Gut } \\
\text { content }\end{array}$ & C-IM & Allo & Lactobacillaceae* & Pinoargote et al. 2018 \\
\hline & Aquaculture & Gl tract & C-IM & Allo+auto & $\begin{array}{l}\text { Lactobacillaceae*, Leuconostocaceae* } \\
\text { and Streptococcaceae* }\end{array}$ & Xue et al., 2018 \\
\hline & Aquaculture & Gl tract & C-IM & Allo & Lactobacillus sp. & Fan et al., 2019 \\
\hline & Aquaculture & Gl tract & C-IM & Allo+auto & Lactobacillus sp. and Streptococcus sp. & Gao et al., 2019b \\
\hline & Aquaculture & Gl tract & C-IM & Allo+auto & Lactococcus sp. & Pei et al., 2019 \\
\hline $\begin{array}{l}\text { White shrimp (Penaeus } \\
\text { vannamei) }\end{array}$ & Natural & GI tract & Cultivation & Allo & Lb. plantarum ${ }^{3}$ and $\mathrm{LAB}^{*}$ & $\begin{array}{l}\text { Kongnum and Hongpattarakere, } \\
2012\end{array}$ \\
\hline
\end{tabular}




\begin{tabular}{|c|c|c|c|c|c|c|}
\hline & Aquaculture & GI tract & C-IM & Allo+auto & Lactobacillus sp. and Lactococcus sp. & Sun et al., 2016 \\
\hline & Aquaculture & GI tract & C-IM & Allo+auto & $\begin{array}{l}\text { Lactococcus sp., Lac. garvieae and } \\
\text { Lactobacillaceae* }\end{array}$ & Gainza et al., 2018 \\
\hline $\begin{array}{l}\text { Brown shrimp } \\
\text { (Farfantepenaeus } \\
\text { californiensis) }\end{array}$ & Aquaculture & GI tract & Cultivation & Allo+auto & P. pentosaceus and LAB* & Leyva-Madrigal et al., 2011 \\
\hline \multirow{2}{*}{$\begin{array}{l}\text { Indian white shrimp } \\
\text { (Penaeus indicus) }\end{array}$} & ni & GI tract & Cultivation & Allo+auto & $\mathrm{LAB}^{* 4}$ & Gopalakannan, 2006 \\
\hline & Natural/ wild & GI tract & Cultivation & Allo+auto & Str. Phocae Pl80 & Kanmani et al., 2010 \\
\hline $\begin{array}{l}\text { Kuruma shrimp } \\
\text { (Marsupenaeus japonicus) }\end{array}$ & Natural/ wild & GI tract & Cultivation & Allo+auto & $\begin{array}{l}\text { E. faecalis, E. faecium, E. pseudovium, E. } \\
\text { raffinosus, Lactobacillus sp. Lb. } \\
\text { plantarum, Lb. nagelii, Lac. garvieae, } \\
\text { Lac. lactis, P. pentosaceus, } \\
\text { Vc. campiphilus and Vc. fluvialis }\end{array}$ & Maeda et al., 2014 \\
\hline \multirow{3}{*}{$\begin{array}{l}\text { Giant tiger prawn (Penaeus } \\
\text { monodon) }\end{array}$} & $\mathrm{ni}$ & GI tract & Cultivation & Allo+auto & $\mathrm{LAB}^{* 4}$ & Gopalakannan, 2006 \\
\hline & ni & GI tract & Cultivation & Allo+auto & Enterococcus sp. $\mathrm{S2}^{3}$ & Nimrat et al., 2013 \\
\hline & $\begin{array}{l}\text { Natural/wild } \\
\text { and } \\
\text { aquaculture }\end{array}$ & GI tract & C-IM & Auto & Lactobacillus sp. and Lactococcus sp. & Rungrassamee et al., 2014 \\
\hline
\end{tabular}




\begin{tabular}{|c|c|c|c|c|c|c|}
\hline $\begin{array}{l}\text { Yellow shrimp } \\
\text { (Metapenaeus brevicornis) }\end{array}$ & Natural & Gl tract & Cultivation & Allo & LAB* & $\begin{array}{l}\text { Kongnum and Hongpattarakere, } \\
2012\end{array}$ \\
\hline \multirow{2}{*}{$\begin{array}{l}\text { Chinese shrimp } \\
\text { (Fenneropenaeus chinensis) }\end{array}$} & Aquaculture & Gl tract & C-IM & Allo+auto & E. faecalis & Liu et al., $2011^{1}$ \\
\hline & Natural & MG & Cultivation & Allo+auto & LAB* & Sha et al., $2016 \mathrm{~b}$ \\
\hline $\begin{array}{l}\text { Banana shrimp } \\
\text { (Fenneropenaeus } \\
\text { merguiensis) }\end{array}$ & Natural & GI tract & Cultivation & Allo & LAB* & $\begin{array}{l}\text { Kongnum and Hongpattarakere, } \\
2012\end{array}$ \\
\hline \multirow[t]{2}{*}{$\begin{array}{l}\text { European lobster (Homarus } \\
\text { gammarus) }\end{array}$} & Aquaculture & GI tract & $\begin{array}{l}\text { Cultivation } \\
\text { and C-IM }\end{array}$ & Allo+auto & W. confusa and W. cibaria & Daniels et al., $2010^{1}$ \\
\hline & Aquaculture & Gl tract & C-IM & Allo+auto & W. confusa and W. cibaria & Daniels et al., $2013^{1}$ \\
\hline $\begin{array}{l}\text { Narrow clawed crayfish } \\
\text { (Astacus leptodactylus) }\end{array}$ & Aquaculture & GI tract & Cultivation & Auto & LAB* & Nedaei et al., 2019 \\
\hline $\begin{array}{l}\text { Mud crab } \\
\text { (Scylla paramamosain) }\end{array}$ & Aquaculture & GI tract & C-IM & Allo+auto & $\begin{array}{l}\text { Str. mutans (diseased), W. fabaria } \\
\text { (farmed) and bacterium Latobacillales } \\
1247 \text { (hatchery) }\end{array}$ & Li et al., $2012^{1}$ \\
\hline $\begin{array}{l}\text { Swimming crab (Callinectes } \\
\text { sp.) }\end{array}$ & Natural/wild & GI tract & Cultivation & Allo+auto & S. agalactiae & Uaboi-Egbenni et al., $2010^{1}$ \\
\hline $\begin{array}{l}\text { Blue swimming crab } \\
\text { (Portunus pelagicus) }\end{array}$ & Natural/wild & GI tract & Cultivation & Allo+auto & $\begin{array}{l}\text { Lb. plantarum }{ }^{3}, \text { Lb. salivarius }{ }^{3}, L b . \\
\text { rhamnosus }^{3}, W . \text { confusa and } W . \text { cibaria }\end{array}$ & Talpur et al., $2012^{1}$ \\
\hline
\end{tabular}




\begin{tabular}{|c|c|c|c|c|c|c|}
\hline $\begin{array}{l}\text { Swimming crab (Portunus } \\
\text { trituberculatus) }\end{array}$ & Natural/wild & Gl tract & C-IM & Allo+auto & $\begin{array}{l}\text { Carnobacterium, Lactococcus, } \\
\text { Streptococcus and Vagococcus }\end{array}$ & Kim et al., 2017 \\
\hline \multirow{5}{*}{$\begin{array}{l}\text { Chinese mitten crab } \\
\text { (Eriocheir sinensis) }\end{array}$} & Aquaculture & Gl tract & C-IM & Allo+auto & Uncultured Lactococcus sp. & Li et al., 2007 \\
\hline & Aquaculture & GI tract & C-IM & Auto & Latobacillales* & Chen et al., 2015 \\
\hline & Natural/wild & $\begin{array}{l}\text { GI tract } \\
\text { content }\end{array}$ & C-IM & Allo & Lactococcus sp. & Zhang et al. 2016 \\
\hline & Natural/wild & Gl tract & C-IM & Allo+auto & Latobacillales* & Ding et al., 2017 \\
\hline & Natural/wild & $\begin{array}{l}\text { GI tract } \\
\text { (FG, MG } \\
\text { and } H G \text { ) }\end{array}$ & $\mathrm{Cl}-\mathrm{M}$ & Allo+auto & Lactobacillus sp. and Lactococcus sp. & Dong et al., 2018 \\
\hline Abalone (Haliotis asinina) & Aquaculture & Gl tract & Cultivation & Allo & & Sarkono et al., $2010^{1}$ \\
\hline \multirow{2}{*}{$\begin{array}{l}\text { Giant lion`s paw scallop } \\
\text { (Nodipecten subnodosus) }\end{array}$} & Aquaculture & GI tract & Cultivation & Allo+auto & LAB strain NS61 ${ }^{3}$ & Nava-Hernández, $2008^{1}$ \\
\hline & Aquaculture & Gl tract & Cultivation & Allo+auto & $L b$. graminis $^{4}$ and $L b$. plantarum ${ }^{4}$ & Abasolo-Pacheco et al., 2016 \\
\hline Narrow clawed crayfish & Aquaculture & $\begin{array}{l}\text { Hepatopa } \\
\text { ncreas }\end{array}$ & Cultivation & Auto & Presumptive LAB & Safari and Paolucci, 2017 \\
\hline \multirow[t]{2}{*}{ Giant freshwater prawn } & Aquaculture & Muscle & Cultivation & 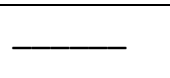 & E. seriolicida & Cheng and Chen, $1998^{1}$ \\
\hline & Aquaculture & Muscle & Cultivation & 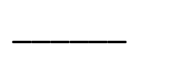 & Lac. lactis subsp. lactis & Wang et al., $2008^{1}$ \\
\hline
\end{tabular}




\begin{tabular}{|c|c|c|c|c|c|c|}
\hline $\begin{array}{l}\text { Shortnek clam (Tapes } \\
\text { philippinarum) }\end{array}$ & Natural/wild & Muscle & Cultivation & - & Lactobacillus sp. ${ }^{4}$ and $L b$. plantarum ${ }^{4}$ & Kang et al., 2016 \\
\hline Turbo (Batillus cornutus) & Natural/wild & Muscle & Cultivation & & Lactobacillus sp. ${ }^{4}$ & Kang et al., 2016 \\
\hline $\begin{array}{l}\text { Chinese venus (Cyclina } \\
\text { sinensis) }\end{array}$ & Natural/wild & Muscle & Cultivation & & Lactobacillus sp. ${ }^{4}$ & Kang et al., 2016 \\
\hline $\begin{array}{l}\text { Blue mussel (Mytilus } \\
\text { edulis) }\end{array}$ & Natural/wild & Muscle & Cultivation & 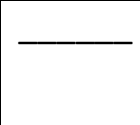 & Lactobacillus sp. ${ }^{4}$ & Kang et al., 2016 \\
\hline $\begin{array}{l}\text { Surf clam (Mactra } \\
\text { veneriformis) }\end{array}$ & Natural/wild & Muscle & Cultivation & & Lactobacillus sp. ${ }^{4}$ & Kang et al., 2016 \\
\hline $\begin{array}{l}\text { Pacific oyster (Crassostrea } \\
\text { gigas) }\end{array}$ & Natural/wild & Muscle & Cultivation & & Lactobacillus sp. ${ }^{4}$ and $L b$. plantarum ${ }^{4}$ & Kang et al., 2016 \\
\hline White shrimp & Aquaculture & $\begin{array}{l}\text { Raw } \\
\text { shrimp }\end{array}$ & Cultivation & & E. lactis ${ }^{4}$ & Braïek et al., 2018 \\
\hline
\end{tabular}

Genera abbreviations: E. - Enterococcus; Lac. - Lactococcus; Lb. - Lactobacillus; P. - Pediococcus; Str. - Streptococcus; Vc. - Vagococcus; W. - Weissella

$1700{ }^{1}$ studies discussed in the review of Merrifield et al. (2014); ${ }^{2}$ exopolysaccharides produced; ${ }^{3}$ used as probiotics; ${ }^{4}$ potential probiotics; ${ }^{*}$ no further information

1701 was given; ni - no information available.

1702 FG - foregut; MG - midgut; HG - hindgut 


\begin{tabular}{|c|c|c|c|c|c|}
\hline Species & Isolated from & Doses and duration & Shellfish species & Parameters investigated & References \\
\hline LAB strains & $\begin{array}{l}\text { National } \\
\text { Collection, Pune, } \\
\text { India }\end{array}$ & $\begin{array}{c}5 \times 10^{6} \text { cells }^{-1} g^{-1}, 4 \\
\text { weeks }\end{array}$ & Penaeus indicus & Resistance against V. parahaemolyticus $\uparrow$ & Ajitha et al., $2004^{1}$ \\
\hline LAB strain NS61 & $\begin{array}{l}\text { Giant lion`s paw } \\
\text { scallop, } \\
\text { Nodipecten } \\
\text { subnodosus }\end{array}$ & $\begin{array}{c}1 \times 10^{4} \text { and } 1 \times 10^{5} \\
\mathrm{CFU} / \mathrm{mL}\end{array}$ & $\begin{array}{c}\text { Cortez oyster } \\
\text { larvae, Crassostrea } \\
\text { corteziensis }\end{array}$ & $\begin{array}{l}\text { Larval survival rate } \uparrow \\
\text { Larval final size } \rightarrow\end{array}$ & $\begin{array}{l}\text { Campa-Córdova et al., } \\
2011\end{array}$ \\
\hline Lactobacillus sp. & $\begin{array}{l}\text { Intestine of } \\
\text { L. vannamei }\end{array}$ & $\begin{array}{l}10^{7} \mathrm{CFU} \mathrm{g}^{-1} \\
27 \text { days }\end{array}$ & $\begin{array}{l}\text { Litopenaeus } \\
\text { vannamei }\end{array}$ & $\begin{array}{l}\text { Digestive enzyme } \uparrow \\
\text { Body weight } \uparrow \\
\text { Resistance against WSSV } \uparrow\end{array}$ & Zuo et al., 2019 \\
\hline Lb. acidophilus & $\begin{array}{l}\text { Homemade curd } \\
\text { isolate }\end{array}$ & $10^{5} \mathrm{CFU} \mathrm{g}^{-1}$ & Penaeus monodon & Resistance against $V$. alginolyticus $\uparrow$ & Sivakumar et al., $2012^{1}$ \\
\hline Lb. bulgaricus & $\begin{array}{l}\text { Intestine of } L \text {. } \\
\text { vannamei }\end{array}$ & $\begin{array}{c}10^{7} \text { and } 10^{9} \mathrm{cfu} \mathrm{g}^{-1} \\
30 \text { days }\end{array}$ & L. vannamei & Immune response and disease resistance $\uparrow$ & Roomiani et al., 2018 \\
\hline Lac. lactis & $\begin{array}{l}\text { Intestine, } \\
\text { Marsupenaeus } \\
\text { japonicus }\end{array}$ & $10^{5} \mathrm{cfu} \mathrm{g}^{-1}$ & $\begin{array}{l}\text { Marsupenaeus } \\
\text { japonicus }\end{array}$ & Resistance to Vibrio penaeicida $\uparrow$ & Maeda et al., 2014 \\
\hline Lac. lactis subsp. lactis & $\begin{array}{l}\text { Intestine, } \\
\text { L. vannamei }\end{array}$ & $\begin{array}{l}10^{6}, 10^{7}, \text { and } \\
10^{8} \mathrm{CFU} \mathrm{g}^{-1}\end{array}$ & L. vannamei & $\begin{array}{l}\text { Growth performance } \uparrow \\
\text { Activities of digestive enzymes } \uparrow \\
\text { Lactobacillus and Bacillus counts } \uparrow \\
\text { Vibrio counts } \downarrow \\
\text { Resistance against } V \text {. anguillarum } \uparrow\end{array}$ & Milad Adel et al., 2017 \\
\hline Lb. pentosus & $\begin{array}{l}\text { Intestinal tract } \\
\text { of abalone }\end{array}$ & $\begin{array}{c}10^{3}, 10^{5} \text {, and } 10^{7} \mathrm{cfu} \\
\mathrm{g}^{-1} \\
8 \text { weeks }\end{array}$ & $\begin{array}{c}\text { Haliotis discus } \\
\text { hannai }\end{array}$ & $\begin{array}{l}\text { SR, Food intake } \uparrow \\
\text { Shell length-specific growth rate } \uparrow \\
\text { FCR } \downarrow \\
\text { Antioxidant capacity } \uparrow \\
\text { Resistance against } V \text {. parahaemolyticus } \uparrow\end{array}$ & Gao et al., 2018 \\
\hline
\end{tabular}




\begin{tabular}{|c|c|c|c|c|c|}
\hline Lb. pentosus & $\begin{array}{l}\text { Gut of } \\
\text { Chaeturichthys } \\
\text { stigmatias }\end{array}$ & $\begin{array}{c}5 \times 10^{8} \mathrm{CFU} \mathrm{g} \mathrm{feed}^{-1} \\
4 \text { weeks }\end{array}$ & L. vannamei & $\begin{array}{l}\text { Digestion related enzymes } \\
\text { Resistance against } V \text {. parahaemolyticus } \uparrow \\
\text { Induced stress response genes expression } \uparrow\end{array}$ & Du et al., 2019 \\
\hline Lb. plantarum & $\begin{array}{l}\text { Intestine of } \\
\text { L. vannamei }\end{array}$ & $\begin{array}{l}10^{8} \mathrm{CFU} \mathrm{mL}^{-1} \\
60 \text { days }\end{array}$ & L. vannamei & $\begin{array}{l}\text { Shrimp survival } \rightarrow \\
\text { Vibrio spp. count } \rightarrow \\
\text { Total lactic bacteria } \uparrow \\
\text { Resistance against } V \text {. harveyi } \uparrow\end{array}$ & Vieira et al., $2010^{1}$ \\
\hline Lb. plantarum & $\begin{array}{l}\text { Intestine of } \\
\text { L. vannamei }\end{array}$ & $\begin{array}{l}2-4 \times 10^{8} \mathrm{CFU} \mathrm{g}^{-1} \\
\text { feed } \\
6 \text { weeks }\end{array}$ & L. vannamei & $\begin{array}{l}\text { Relative growth rate } \uparrow, \text { FCR } \downarrow \\
\text { Survival rate } \uparrow \\
\text { Hemocytes count } \uparrow \\
\text { Resistance against } V \text {. harveyi } \uparrow\end{array}$ & $\begin{array}{l}\text { Kongnum and } \\
\text { Hongpattarakere, } 2012\end{array}$ \\
\hline Lb. plantarum & $\begin{array}{l}\text { Culture } \\
\text { collection }\end{array}$ & $\begin{array}{l}10^{7}, 10^{8}, \text { and } \\
10^{9} \mathrm{CFU} \mathrm{g}^{-1} \text { diet } \\
90 \text { days }\end{array}$ & $\begin{array}{l}\text { Macrobrachium } \\
\text { rosenbergii }\end{array}$ & $\begin{array}{l}\text { WG, SGR, FCE, PER } \uparrow \\
\text { FCR } \downarrow, \text { Carcass protein content } \uparrow\end{array}$ & Dash et al., 2014 \\
\hline Lb. plantarum & $\begin{array}{l}\text { Culture } \\
\text { collection }\end{array}$ & $\begin{array}{l}10^{7}, 10^{8}, \text { and } \\
10^{9} \mathrm{CFU} \mathrm{g}^{-1} \text { diet } \\
90 \text { days }\end{array}$ & M. rosenbergii & $\begin{array}{l}\text { WG, SGR, FCE, PER } \uparrow \\
\text { FCR } \downarrow \text {, Carcass protein content } \uparrow \\
\text { Resistance against Aeromonas hydrophila }\end{array}$ & Dash et al., 2015 \\
\hline Lb. plantarum & $\begin{array}{l}\text { Culture } \\
\text { collection }\end{array}$ & $\begin{array}{l}10^{7}, 10^{8} \text {, and } \\
10^{9} \mathrm{CFU} \mathrm{L}^{-1} \text { diet } \\
90 \text { days }\end{array}$ & M. rosenbergii & $\begin{array}{l}\text { WG, SGR, FCE, PER } \uparrow \\
\text { FCR } \downarrow \text {, Carcass protein content } \uparrow \\
\text { Water quality } \rightarrow\end{array}$ & Dash et al., 2016 \\
\hline Lb. plantarum & Shrimp intestine & $\begin{array}{c}1.0 \times 10^{7} \mathrm{CFU} \mathrm{mL}^{-1} \\
35 \text { days }\end{array}$ & L. vannamei & $\begin{array}{l}\text { Growth performance } \rightarrow \\
\text { Water quality } \rightarrow\end{array}$ & Correa et al., 2018 \\
\hline Lb. plantarum & & $\begin{array}{c}20 \times 10^{3} \text { cells } \\
\mathrm{mL}^{-1} \text { and } \\
1 \times 10^{8}(\mathrm{CFU}) \mathrm{mL}^{-1}\end{array}$ & L. vannamei & $\begin{array}{l}\text { Improve water quality in biofloc system } \uparrow \\
\text { Reduce shrimp diseases and environmental } \\
\text { impact } \downarrow\end{array}$ & $\begin{array}{l}\text { Pacheco-Vega et al., } \\
2018\end{array}$ \\
\hline Lb. plantarum & $\begin{array}{l}\text { Commercial } \\
\text { probiotic }\end{array}$ & $\begin{array}{l}10^{9} \mathrm{CFU} \mathrm{mL}^{-1} \\
15 \text { days }\end{array}$ & L. vannamei & $\begin{array}{l}\text { Final weight, WG, SGR } \uparrow, \text { FCR } \downarrow \\
\text { Digestive enzyme activities } \uparrow \\
\text { Enterocytes height } \uparrow\end{array}$ & Zheng et al., 2018 \\
\hline Lb. plantarum & $\begin{array}{l}\text { Commercial } \\
\text { probiotic }\end{array}$ & $\begin{array}{l}10^{9} \mathrm{CFU} \mathrm{mL}^{-1} \\
45 \text { days }\end{array}$ & L. vannamei & $\begin{array}{l}\text { Final weight, WG, SGR } \uparrow, F C R \downarrow \\
\text { Improved the resistance against the stress of } \\
\text { acute low salinity } \uparrow\end{array}$ & Zheng et al., 2017 \\
\hline
\end{tabular}




\begin{tabular}{|c|c|c|c|c|c|}
\hline Lb. sporogenes & $\begin{array}{l}\text { Commercial } \\
\text { probiotic }\end{array}$ & $\begin{array}{c}0 \%, 1 \%, 2 \%, 3 \% \text { and } \\
4 \% \\
90 \text { days }\end{array}$ & M. rosenbergii & $\begin{array}{l}\text { SR, WG, SGR, FCE and PER } \uparrow, \text { FCR } \downarrow \\
\text { Total protein, total free amino acid, total } \\
\text { carbohydrate, and total lipid content } \uparrow \\
\text { Feeding rate, absorption rate, conversion } \\
\text { rate and excretory rate } \uparrow\end{array}$ & Seenivasan et al., 2014) \\
\hline P. acidilactici & $\begin{array}{l}\text { Commercial } \\
\text { probiotic }\end{array}$ & $\begin{array}{c}10^{7} \mathrm{CFU} \mathrm{g}^{-1} \text { of feed } \\
1 \text { month }\end{array}$ & $\begin{array}{l}\text { Litopenaeus } \\
\text { stylirostris }\end{array}$ & $\begin{array}{l}\text { Antioxidant status } \uparrow \\
\text { Resistance against } V \text {. nigripulchritudo } \uparrow\end{array}$ & Castex et al., $2010^{1}$ \\
\hline P. pentosaceus & $\begin{array}{l}\text { Intestine of } \\
\text { L. vannamei }\end{array}$ & $\begin{array}{l}0,10^{6}, 10^{7} \text {, and } 10^{8} \\
\text { CFU/g diet } \\
8 \text { weeks }\end{array}$ & L. vannamei & $\begin{array}{l}\text { Final weight, final length, WG, SR, WG } \uparrow \\
\text { FCR } \downarrow \\
\text { Protease and amylase activities } \uparrow \\
\text { Lactobacillus sp. and Bacillus sp. intestinal } \\
\text { count } \uparrow\end{array}$ & Adel et al., 2017 \\
\hline $\begin{array}{l}\text { E. faecium and } L b . \\
\text { pentosus }\end{array}$ & $\begin{array}{l}\text { Gut of } \\
\text { Fenneropenaeus } \\
\text { chinensis) and } \\
\text { Chaeturichthys } \\
\text { stigmatias } \\
\end{array}$ & $1 \times 10^{7} \mathrm{CFU}_{\mathrm{g} \text { feed }}{ }^{-1}$ & L. vannamei & Resistance against V. parahaemolyticus $\uparrow$ & Sha et al., $2016 \mathrm{~b}$ \\
\hline $\begin{array}{l}\text { E. faecalis and } E \text {. } \\
\text { faecium }\end{array}$ & $\begin{array}{l}\text { Intestine of } \\
\text { Prawn and } \\
\text { mullet }\end{array}$ & - & L. vannamei & $\begin{array}{l}\text { Resistance against } A \text {. hydrophila and } \\
\text { V. vulnificus } \uparrow\end{array}$ & Cui et al., 2017 \\
\hline $\begin{array}{l}\text { Lb. pentosus, Lac. } \\
\text { fermentum, Bacillus } \\
\text { subtilis, Saccharomyces } \\
\text { cerevisiae }\end{array}$ & $\begin{array}{l}\text { Commercial } \\
\text { probiotic }\end{array}$ & $\begin{array}{c}10^{7}, 10^{8} \text { and } 10^{9} \mathrm{CFU} \\
{\text { (kg diet })^{-1}} \\
56 \text { days }\end{array}$ & L. vannamei & $\begin{array}{l}\text { Growth performance } \uparrow \\
\text { Survival rate } \uparrow, \text { Carcass composition } \rightarrow \\
\text { Resistance against } V \text {. parahaemolyticus } \uparrow\end{array}$ & Wang et al., 2019 \\
\hline
\end{tabular}

Genera abbreviations: E. - Enterococcus; Lac. - Lactococcus; Lb. - Lactobacillus; P. - Pediococcus; Str. - Streptococcus; W. - Weissella; V. - Vibrio.

1706 Weight gain (WG), Specific growth rate (SGR), Food conversion efficiency (FCE), Food conversion ratio (FCR), Protein efficiency ratio (PER), Survival rate (SR)

$1707{ }^{1}$ studies discussed in the review of Hoseinifar et al. (2018) 


\begin{tabular}{|c|c|c|c|c|c|c|}
\hline $\begin{array}{l}\text { Shellfish } \\
\text { phylum }\end{array}$ & LAB species & $\begin{array}{c}\text { Experimental animals } \\
\text { (weight) }\end{array}$ & $\begin{array}{l}\text { Administration } \\
\text { routs and dose }\end{array}$ & $\begin{array}{l}\text { Administrat } \\
\text { ion length }\end{array}$ & Immune parameter changes & References \\
\hline \multirow[t]{3}{*}{ Crustacean } & \multirow[t]{2}{*}{ Lb. plantarum 7-40 } & $\begin{array}{l}\text { Juvenile mud crab } \\
\text { (Scylla } \\
\text { paramamosain) } \\
\text { (0.97 } \pm 0.14 \mathrm{~g} \text { ) }\end{array}$ & $\begin{array}{l}\text { Diet, } \\
10^{9} \mathrm{CFU} / \mathrm{kg} \\
\text { feeding }\end{array}$ & 28 days & $\begin{array}{l}\text { Survival rate against Vibrio } \\
\text { parahaemolyticus }\left(10^{5} \mathrm{CFU} / \mathrm{crab}\right) \uparrow, \\
\text { Total hemocyte count } \uparrow, \\
\text { Phenoloxidase activity } \uparrow, \\
\text { Phagocytic activity } \uparrow\end{array}$ & Yeh et al., 2014 \\
\hline & & $\begin{array}{l}\text { Intermolt stage white } \\
\text { shrimp (stage C) } \\
\text { (Litopenaeus } \\
\text { vannamei) } \\
\text { (Weight is not } \\
\text { mentioned) }\end{array}$ & $\begin{array}{l}\text { Diet, } \\
10^{7}, 10^{10} \mathrm{CFU} / \mathrm{kg} \\
\text { feeding }\end{array}$ & 14 days & $\begin{array}{l}\text { Until } 48 \mathrm{~h} \text { : } \\
\text { Total hemocyte count } \downarrow, \\
\text { Phenoloxidase activity } \downarrow, \\
\text { After } 48 \mathrm{~h} \text { : } \\
\text { Respiratory burst } \uparrow, \\
\text { Superoxide dismutase activity } \uparrow, \\
\text { Clearance efficiency } \uparrow, \\
\text { Prophenoloxidase mRNA } \uparrow, \\
\text { Peroxinectin mRNA } \uparrow\end{array}$ & Chiu et al., 2007 \\
\hline & $\begin{array}{l}\text { Lb. plantarum PPG- } \\
\text { 2-10-Talpur }\end{array}$ & $\begin{array}{l}\text { Swimming crab larvae } \\
\text { zoea } 1 \text { (Z-1) } \\
\text { (Portunus pelagicus) }\end{array}$ & $\begin{array}{l}\text { Immersion } \\
1,5,10 \times 10^{6} \\
\mathrm{CFU} / \mathrm{mL}\end{array}$ & 14 days & Survival rate $\uparrow$ & Talpur et al., 2013 \\
\hline
\end{tabular}




\begin{tabular}{|c|c|c|c|c|c|}
\hline & $\begin{array}{l}\text { (Weight is not } \\
\text { mentioned) }\end{array}$ & & & & \\
\hline Lb. pentosus HC-2 & \multirow[t]{2}{*}{$\begin{array}{l}\text { White shrimp } \\
\text { (Litopenaeus } \\
\text { vannamei) } \\
(3.5 \pm 0.06 \mathrm{~g})\end{array}$} & \multirow[t]{2}{*}{$\begin{array}{l}\text { Diet, } \\
10^{7} \mathrm{CFU} / \mathrm{g} \\
\text { feeding }\end{array}$} & \multirow[t]{2}{*}{$\begin{array}{l}2 \text { weeks and } \\
4 \text { weeks }\end{array}$} & $\begin{array}{l}\text { Midgut: } \\
\text { Penaeidins-3 } \alpha \text { mRNA } \uparrow, \\
\text { Prophenoloxidase mRNA } \uparrow, \\
\text { Hepatopancreas: } \\
\text { Prophenoloxidase mRNA } \uparrow, \\
\text { Crustin mRNA } \uparrow, \\
\text { Lysozyme mRNA } \uparrow\end{array}$ & \multirow[t]{2}{*}{ Sha et al., 2016b } \\
\hline E. faecium NRW-2 & & & & $\begin{array}{l}\text { Midgut, } \\
\text { Penaeidins-3 } \alpha \text { mRNA } \uparrow, \\
\text { Prophenoloxidase mRNA } \uparrow, \\
\text { Lysozyme mRNA } \uparrow, \\
\text { Crustin mRNA } \uparrow, \\
\text { Hepatopancreas: } \\
\text { Crustin mRNA } \uparrow, \\
\text { Lysozyme mRNA } \uparrow\end{array}$ & \\
\hline Lb. pentosus BD6 & $\begin{array}{l}\text { Juvenile white shrimp } \\
\text { (Litopenaeus } \\
\text { vannamei) } \\
(0.21 \pm 0.01 \mathrm{~g})\end{array}$ & $\begin{array}{l}\text { Diet, } \\
4.1 \times 10^{9} \mathrm{CFU} / \mathrm{kg} \\
\text { feeding }\end{array}$ & 56 days & $\begin{array}{l}\text { Survival rate against Vibrio } \\
\text { alginolyticus ( } 10^{5} \mathrm{CFU} / \text { shrimp) } \uparrow, \\
\text { Phenoloxidase activity } \uparrow, \\
\text { Respiratory burst } \uparrow,\end{array}$ & Wang et al., 2019 \\
\hline
\end{tabular}




\begin{tabular}{|c|c|c|c|c|c|}
\hline & & & & $\begin{array}{l}\text { Lysozyme activity } \uparrow, \\
\text { Phagocytic activity } \uparrow\end{array}$ & \\
\hline Lb. fermentum LW2 & & $\begin{array}{l}\text { Diet, } \\
0.9 \times 10^{9} \mathrm{CFU} / \mathrm{kg} \\
\text { feeding }\end{array}$ & & $\begin{array}{l}\text { Survival rate against } V \text {. alginolyticus } \\
\left(10^{5} \mathrm{CFU} / \text { shrimp }\right) \uparrow, \\
\text { Lysozyme activity } \uparrow, \\
\text { Superoxide dismutase activity } \uparrow, \\
\text { Phagocytic activity } \uparrow\end{array}$ & \\
\hline S. cerevisiae $\mathrm{P} 13$ & & $\begin{array}{l}\text { Diet, } \\
1.6 \times 10^{9} \mathrm{CFU} / \mathrm{kg} \\
\text { feeding }\end{array}$ & & $\begin{array}{l}\text { Survival rate against } V \text {. alginolyticus } \\
\left(10^{5} \mathrm{CFU} / \text { shrimp }\right) \uparrow, \\
\text { Phenoloxidase activity } \uparrow, \\
\text { Phagocytic activity } \uparrow\end{array}$ & \\
\hline $\begin{array}{l}\text { Multi-LABs } \\
\text { (Lb. acidophilus, } \\
\text { Lb. casei, } \\
\text { E. faecium and } \\
\text { B. bifidium) } \\
\text { (strains are not } \\
\text { mentioned) }\end{array}$ & $\begin{array}{l}\text { Juvenile white shrimp } \\
\text { (Litopenaeus } \\
\text { vannamei) } \\
(0.47 \pm 0.02 \mathrm{~g})\end{array}$ & $\begin{array}{l}\text { Diet, } \\
0.25,0.5,1.0 \\
\mathrm{~g} / \mathrm{kg} \text { feeding }\end{array}$ & 60 days & $\begin{array}{l}\text { Prophenoloxidase mRNA } \uparrow, \\
\text { Lysozyme mRNA } \uparrow, \\
\text { Penaidian mRNA } \uparrow, \\
\text { Crustin mRNA } \uparrow\end{array}$ & $\begin{array}{l}\text { Miandare et al., } \\
2016\end{array}$ \\
\hline Lb. plantarum & $\begin{array}{l}\text { Post-larvae white } \\
\text { shrimp }\end{array}$ & $\begin{array}{l}\text { Diet, } \\
1.5 \times 10^{8} \mathrm{CFU} / \mathrm{g} \\
\text { feeding. }\end{array}$ & 60 days & $\begin{array}{l}\text { Survival rate against Vibrio harveyi } \\
\left(2.5 \times 10^{5} \mathrm{CFU} / \text { shrimp }\right) \uparrow, \\
\text { Total hemocyte count } \uparrow \text {, }\end{array}$ & Vieira et al., 2010 \\
\hline
\end{tabular}




\begin{tabular}{|c|c|c|c|c|c|}
\hline & $\begin{array}{l}\text { (Litopenaeus } \\
\text { vannamei) } \\
(0.08 \pm 0.01 \mathrm{~g})\end{array}$ & & & $\begin{array}{l}\text { Phenoloxidase activity } \uparrow, \\
\text { Agglutinating activity } \uparrow\end{array}$ & \\
\hline Lac. lactis D1813 & $\begin{array}{l}\text { Kuruma shrimp } \\
\text { (Marsupenaeus } \\
\text { japonicus) } \\
(4.7 \pm 0.3 \mathrm{~g})\end{array}$ & $\begin{array}{l}\text { Diet, } \\
10^{5}, 10^{7} \mathrm{CFU} / \mathrm{g} \\
\text { feeding }\end{array}$ & 7 days & $\begin{array}{l}\text { Survival rate against Vibrio penaeicida } \\
\left(10^{8} \mathrm{CFU} / \mathrm{mL}\right) \uparrow, \\
\text { Intestine: } \\
\text { Crustin mRNA } \uparrow \text {, } \\
\text { Anti-LPS factor mRNA } \uparrow, \\
\text { Lysozyme mRNA } \uparrow \text {, } \\
\text { Superoxide dismutase mRNA } \uparrow, \\
\text { Prophenoloxidase mRNA } \uparrow, \\
\text { Toll-like receptor } 1 \text { mRNA } \uparrow \\
\text { Hepatopancreas: } \\
\text { Anti-LPS factor mRNA } \uparrow, \\
\text { Lysozyme mRNA } \uparrow\end{array}$ & $\begin{array}{l}\text { Maeda et al., } \\
2014\end{array}$ \\
\hline \multirow[t]{2}{*}{$\begin{array}{l}\text { Lb. plantarum } \\
\text { MTCC1407 }\end{array}$} & \multirow{2}{*}{$\begin{array}{l}\text { Juvenile giant } \\
\text { freshwater prawn } \\
\text { (Macrobrachium } \\
\text { rosenbergii) }\end{array}$} & $\begin{array}{l}\text { Diet, } \\
10^{7}, 10^{8}, 10^{9} \\
\text { CFU/g feeding }\end{array}$ & \multirow[t]{2}{*}{90 days } & \multirow{2}{*}{$\begin{array}{l}\text { Survival rate against Aeromonas } \\
\text { hydrophila }\left(10^{6} \mathrm{CFU} / \text { prawn }\right) \uparrow, \\
\text { Total hemocyte count } \uparrow, \\
\text { Phenoloxidase activity } \uparrow,\end{array}$} & Dash et al., 2014 \\
\hline & & $\begin{array}{l}\text { Immersion, } \\
10^{7}, 10^{8}, 10^{9} \\
\text { CFU/L }\end{array}$ & & & Dash et al., 2016 \\
\hline
\end{tabular}




\begin{tabular}{|c|c|c|c|c|c|c|}
\hline & $\begin{array}{l}\text { Heat-killed } L b . \\
\text { plantarum } \\
\text { MTCC1407 }\end{array}$ & $(0.54 \pm 0.03 \mathrm{~g})$ & $\begin{array}{l}\text { Diet, } \\
10^{7}, 10^{8}, 10^{9} \\
\text { CFU/g feeding }\end{array}$ & & $\begin{array}{l}\text { Respiratory burst } \uparrow, \\
\text { Hemolymph clearance efficiency } \uparrow\end{array}$ & Dash et al., 2015 \\
\hline & $\begin{array}{l}\text { P. acidilactici } \\
\text { (strains are not } \\
\text { mentioned) }\end{array}$ & \multirow{2}{*}{$\begin{array}{l}\text { Juvenile narrow- } \\
\text { clawed crayfish } \\
\text { (Astacus } \\
\text { leptodactylus) } \\
(6.17 \pm 0.03 \mathrm{~g})\end{array}$} & $\begin{array}{l}\text { Diet, } \\
7.53 \text { log CFU/g } \\
\text { feeding }\end{array}$ & \multirow[t]{2}{*}{126 days } & $\begin{array}{l}\text { Survival rate against } A \text {. hydrophila } \\
\left(10^{8} \mathrm{CFU} / \mathrm{mL}\right) \uparrow, \\
\text { Total hemocyte count } \uparrow,\end{array}$ & \multirow[t]{2}{*}{ Safari et al., 2017} \\
\hline & $\begin{array}{l}\text { E. faecalis } \\
\text { (strains are not } \\
\text { mentioned) }\end{array}$ & & $\begin{array}{l}7.53 \log \text { CFU/g } \\
\text { feeding }\end{array}$ & & $\begin{array}{l}\text { Phenoloxidase activity } \uparrow, \\
\text { Superoxide dismutase activity } \uparrow, \\
\text { Lysozyme activity } \uparrow, \\
\text { Nitric oxide synthase activity } \uparrow\end{array}$ & \\
\hline \multirow[t]{5}{*}{ Mollusca } & Lb. graminis RL5 & \multirow{2}{*}{$\begin{array}{l}\text { Juvenile Kumamoto } \\
\text { oyster } \\
\text { (Crassostrea sikamea) } \\
(37.33 \pm 0.07 \mathrm{mg} \text { ) }\end{array}$} & \multirow{2}{*}{$\begin{array}{l}\text { Immersion, } \\
10^{6} \mathrm{CFU} / \mathrm{mL}\end{array}$} & \multirow[t]{2}{*}{35 days } & \multirow[t]{2}{*}{ Vibrio spp. Inhibitory activity $\uparrow$} & \multirow{2}{*}{$\begin{array}{l}\text { Abasolo-Pacheco } \\
\text { et al., } 2016\end{array}$} \\
\hline & Lb. plantarum C & & & & & \\
\hline & Lb. graminis RL5 & \multirow{2}{*}{$\begin{array}{l}\text { Catarina scallop } \\
\text { (Argopecten } \\
\text { ventricosus) } \\
(13.3 \pm 0.03 \mathrm{mg})\end{array}$} & \multirow{2}{*}{$\begin{array}{l}\text { Immersion, } \\
10^{6} \mathrm{CFU} / \mathrm{mL}\end{array}$} & \multirow[t]{2}{*}{21 days } & \multirow{2}{*}{$\begin{array}{l}\text { Survival rate against } V \text {. alginolyticus } \\
\left(10^{7} \mathrm{CFU} / \mathrm{mL}\right) \uparrow \text {, } \\
\text { Superoxide dismutase activity } \downarrow\end{array}$} & \multirow{2}{*}{$\begin{array}{l}\text { Abasolo-Pacheco } \\
\text { et al., } 2017\end{array}$} \\
\hline & Lb. plantarum C & & & & & \\
\hline & $\begin{array}{l}\text { Enterococcus spp. } \\
\text { JHLDc }\end{array}$ & $\begin{array}{l}\text { New Zealand abalone } \\
\text { (Haliotis iris) }\end{array}$ & $\begin{array}{l}\text { Diet, } \\
3 \times 10^{9} \mathrm{CFU} / \mathrm{g} \\
\text { feeding }\end{array}$ & 60 days & Survival rate $\uparrow$ & Hadi et al., 2014 \\
\hline
\end{tabular}




\begin{tabular}{|c|c|c|c|c|c|c|}
\hline & \multirow{2}{*}{$\begin{array}{l}\text { (mixed with } \\
\text { Exiguobacterium } \\
\text { spp., Vibrio spp.) } \\
\text { (species are not } \\
\text { mentioned) }\end{array}$} & $\begin{array}{l}\text { (Weight is not } \\
\text { mentioned) }\end{array}$ & & & & \\
\hline & & $\begin{array}{l}\text { New Zealand abalone } \\
\text { (Haliotis iris) } \\
(2.14 \pm 1.19 \mathrm{~g} \text { ) }\end{array}$ & $\begin{array}{l}\text { Diet, } \\
2 \times 10^{9} \mathrm{CFU} / \mathrm{g} \\
\text { feeding }\end{array}$ & 16 weeks & $\begin{array}{l}\text { Total hemocyte count } \uparrow, \\
\text { Hemocyte viability } \uparrow, \\
\text { Reactive oxygen species resistant- } \\
\text { hemocyte count } \uparrow \text {, } \\
\text { Non-apoptotic cell } \uparrow \text {, } \\
\text { Early, late apoptotic cell } \downarrow\end{array}$ & $\begin{array}{l}\text { Grandiosa et al., } \\
2018\end{array}$ \\
\hline Echinodermata & $\begin{array}{l}\text { Lactobacillus, } \\
\text { (mixed with } \\
\text { Sphingomonas and } \\
\text { Acetobacter) } \\
\text { (species are not } \\
\text { mentioned) }\end{array}$ & $\begin{array}{l}\text { Sea cucumber } \\
\text { (Apostichopus } \\
\text { japonicus) } \\
(0.63 \pm 0.13 \mathrm{~g})\end{array}$ & $\begin{array}{l}\text { Diet, } \\
6,9 \times 10^{7} \mathrm{CFU} / \mathrm{g} \\
\text { feeding }\end{array}$ & 90 days & $\begin{array}{l}\text { Superoxide dismutase activity } \uparrow, \\
\text { Catalase activity } \uparrow, \\
\text { Acid phosphatase activity } \uparrow, \\
\text { Alkaline phosphatase activity } \uparrow, \\
\text { Lysozyme activity } \uparrow\end{array}$ & Bao et al., 2017 \\
\hline
\end{tabular}

